\title{
TWO NEW MEASURES OF BANKRUPTCY EFFICIENCY
}

\author{
by \\ Riccardo Brogi and Paolo Santella
}

SUERF - The European Money and Finance Forum

Vienna 2004 
CIP

\section{TWO NEW MEASURES OF BANKRUPTY EFFICIENCY}

by Riccardo Brogi and Paolo Santella

Vienna: SUERF (SUERF Studies: 2004/6)

ISBN 3-902109-25-4

Keywords: Bankruptcy, insolvency, corporate governance, banking, regulation efficiency.

JEL Classification Numbers: G33

(C) 2004 SUERF, Vienna

Copyright reserved. Subject to the exception provided for by law, no part of this publication may be reproduced and/or published in print, by photocopying, on microfilm or in any other way without the written consent of the copyright holder(s); the same applies to whole or partial adaptations. The publisher retains the sole right to collect from third parties fees payable in respect of copying and/or take legal or other action for this purpose. 


\title{
TWO NEW MEASURES OF BANKRUPTCY EFFICIENCY ${ }^{1}$
}

\author{
By Riccardo Brogi ${ }^{2}$ and Paolo Santella ${ }^{3}$
}

\section{Corresponding author:}

\author{
Riccardo Brogi \\ Regulatory Impact Assessment Department \\ Associazione Bancaria Italiana \\ Piazza del Gesù 49 \\ I-00186 Rome \\ ITALY \\ Tel: +39066767402 (Phone) \\ Fax: +390667678030 (Fax) \\ E-mail: r.brogi@abi.it
}

\footnotetext{
${ }^{1}$ The findings, interpretations and conclusions expressed in this paper are entirely those of the authors. They do not necessarily represent the views of the Associazione Bancaria Italiana, Banca d'Italia or OECD. Riccardo Brogi thanks for the very helpful comments and insights from Pietro Scabellone and Gianfranco Torriero and Cristina Raponi for research assistance with regard to New Basel Capital Accord formulas. Paolo Santella wishes to thank Enrico Baffi, Luigi Cannari, Stefano Cappiello, Salvatore Chiri, Silvia Giacomelli and Massimo Omiccioli for their for help and guidance.

${ }^{2}$ Associazione Bancaria Italiana

${ }^{3}$ European Commission and Banca d'Italia
} 



\begin{abstract}
This study is aimed at developing new empirical models for evaluating the efficiency of bankruptcy legislations. The paper is divided in three parts. In the first part, we analyze from a conceptual point of view the effects on debtor firms of the lack of creditors' powers in bankruptcy. In the second part, we develop a new rating method for bankruptcy legislations according to their degree of creditors' protection and apply it to five European countries. In the third part, we introduce a new approach for empirically estimating the efficiency of bankruptcy legislation based on the cost of banking credit and we test it on the Italian case. In particular, the unprecedented tool being used in the third section consists of the New Basel Capital Accord, i.e. the capital adequacy regulatory framework that is about to be put into effect as of the end of 2006.
\end{abstract}





\section{TABLE OF CONTENTS}

1. Some remarks about the lack of creditors' powers in bankruptcy 9

1.1 Credit Recovery and Corporate Governance 9

1.2. Bankruptcy and creditors coordination 11

1.3. The inadequacy of Italian legislation 12

1.4. The costs of the inefficiency of bankruptcy legislation 13

1.5. Conclusion 14

2. A rating method for bankruptcy legislations 17

2.1. Bankruptcy procedures according to creditors' protection and length

2.2. Other relevant factors: obstacles to the conclusion of direct agreements between creditors and debtor and cost of enforcement proceedings. $\quad 26$

2.3. Conclusion 28

3. A Basel II - based quantitative application to bankruptcy in Italy 29

3.1. Insolvency costs: a review of literature 29

3.2. Estimating the impact of insolvency regulation: a new
approach

3.3. Estimating the impact of Italian insolvency law: an empirical application of the new approach $\quad 35$

3.4. Conclusion $\quad 42$

4. General conclusion 44

References $\quad 45$

SUERF - Société Universitaire Européenne de Recherches Financières 52

SUERF STUDIES 



\section{Some remarks about the lack of creditors' powers in bankruptcy}

The purpose of this section is firstly to recapitulate and order the main conclusions reached by economists on the functions of bankruptcy and then to show (taking the Italian legislation as an example) the costs of the inadequacy of bankruptcy on debtor enterprises.

\subsection{Credit recovery and corporate governance}

The economic function of bankruptcy ${ }^{4}$ has been investigated by economists specialized in several fields, such as finance, the theory of the firm, the study of property rights and of corporate governance. ${ }^{5}$ Two functions have been singled out as a result:

\section{a) Proper working of the invisible hand mechanism}

The first function of bankruptcy is to allow unpaid creditors to seize the insolvent debtor's assets, sell them and invest the proceeds in other venues.

${ }^{4}$ In this paper we use the terms "bankruptcy legislation" and "bankruptcy" for all the procedures of liquidation, financial restructuring, and crisis prevention that are contained in national legislations. In particular, although "insolvency" and "bankruptcy" have not the same meaning in the United States and in the United Kingdom - in the United States insolvency by a firm is described as bankruptcy, whereas in the United Kingdom such a description is used is applied to individuals - in this research they have almost the same meaning.

${ }^{5}$ See for instance Ronald Coase, The Nature of the Firm, Economica, vol. 4, p. 386-405, 1937; F. A. Hayek, Individualism and Economic Order, Chicago, The University of Chicago Press, 1949; Ronald Coase, The Problem of Social Cost, Journal of law and Economics, vol. 3, 1960; Harold Demsetz, The Exchange and Enforcement of Property Rights, Journal of Law and Economics, ott. 1964, reprinted in Harold Demsetz, Ownership, Control, and the Firm, The Organization of Economic Activity, vol. I, Oxford, Basil Blackwell 1988; Armen A. Alchian, Some Economics of Property Rights, Il Politico, vol. 30, p. 816-29, 1965, reprinted in A. A. Alchian, Economic Forces at Work, Indianapolis, Liberty Press, 1977; Harold Demsetz, Toward a Theory of Property Rights, American Economic Review, May 1967, reprinted in Harold Demsetz, Ownership, Control, and the Firm, The Organization of Economic Activity, vol. I, Oxford, Basil Blackwell 1988; F. A. Hayek, Studies in Philosophy, Politics and Economics, Chicago, The University of Chicago Press, 1967; M.C. Jensen et W. H. Meckling, Theory of the Firm: Managerial Behavior, Agency Costs and Ownership Structure, Journal of Financial Economics, vol. 3, p. 305-60, 1976; Franco Romani, L'analisi economica del diritto di propriet, proceedings of the workshop held by the Acton Society, All Souls College, Oxford, June 1978; S.N.S. Cheung, The Contractual Nature of the Firm, Journal of Law and Economics, April 1983; Franco Romani, Some Notes on the Economic Analysis of Contract Law, in European University Institute, Series A: Law Contract and Organization: legal analysis in the light of economic and social theory, 1986; Michael C. Jensen, Active Investors, LBOs, and the Privatization of Bankruptcy, Continental Bank Journal of Applied Corporate Finance, vol. 2, p. 35-44, 1989. 
On the one hand, in western economic systems decentralized decisions are coordinated through the price system (the so called invisible hand), through which economic agents decide which economic initiatives to encourage. The juridical basis of the price system is given by two fundamental features of western systems, to give owners exclusive control on scarce goods ${ }^{6}$ and to allow transfer of ownership by way of contract. ${ }^{7}$ The result is that goods end up in the hands of those who use them most efficiently.

On the other hand, the modern enterprise (but more generally the enterprise tout court, if we think about the accomandita in the middle ages and the forms of enterprise in the ancient $\mathrm{Rome}^{8}$ ) is founded on the separation of ownership and control, which allows to take advantage of the benefits of specialization between the entrepreneur and the financial investor.

In this context the role of the law is to mediate (or, as an economist would say, to reduce transaction costs) between the exclusivity of control over goods and the necessity to delegate their use. Bankruptcy's pivotal role is due to the fact that it allows creditors to redeem their resources from insolvent enterprises so as to lend them to more profitable venues.

\section{b) Control on the debtor's management}

Bankruptcy legislation coordinates exclusivity of ownership of scarce goods and delegation of their use in a second and not less important way, that is by allowing creditors to monitor the management of the debtor enterprise. While in the former case the function of bankruptcy is to give creditors the right to disinvest from the insolvent enterprise, ensuring the functioning of the exclusivity clause; in this case the threat of bankruptcy, being the main tool creditors have to monitor the debtor enterprise, takes care of the working of the delegation clause. ${ }^{9}$ From this point of view, corporate law and bankruptcy law can be seen as the two complementary legal preconditions which allow

\footnotetext{
${ }^{6}$ A more correct definition should refer not to ownership of goods but to ownership of rights which insist on goods.

${ }^{7}$ See also Anthony de Jasay (1991), Choice, Contract, Consent: A Restatement of Liberalism, London, The Institute of Economic Affairs, and Stig Strömholm (2002), L'Europe et le droit, Paris, Presses Universitaires de France.

${ }^{8}$ On which see for instance H. Hansmann, R. Kraakman and R. Squire (2002), Legal Entities, Asset Partitioning, and the Evolution of Organizations, mimeo.

${ }^{9}$ See M. C. Jensen and W. S. Smith jr. (1984), The Modern Theory of Corporate Finance, New York, McGraw Hill Inc., p. 14: "Some of [the bankruptcy costs] arise because the bankruptcy trustee is an agent of the court and thus has limited incentives to make value-maximizing investment or financing decisions. Good estimates of these costs do not yet exist; but in general, they are unlikely to be trivial." See also Rasmussen and Skeel (1995), p. 93: "Because $\rightarrow$
} 
the financial contributors to the enterprise (shareholders and creditors) to monitor its management. ${ }^{10}$

The efficiency of these instruments is above all in the interest of the debtors themselves: if corporate law allows shareholders to monitor managers this reduces the cost of capital; likewise, if bankruptcy legislation makes the threat of bankruptcy credible, this reduces the cost of credit. Efficient protection of the contributors to the enterprise (shareholders and creditors) makes the former buy the stock of the enterprise at a higher price and the latter give loans at a lower rate of interest.

To sum up, bankruptcy may be seen as a sanctioning device at the hands of creditors in a double sense, either as a right to disinvest from an insolvent enterprise and as a tool to monitor the debtor enterprise's management all along the credit relationship. The conclusion is that every legislator should give directive powers to creditors in bankruptcy.

\subsection{Bankruptcy and creditors coordination}

In this context must be evaluated what further characteristics bankruptcy should have. The debate has been opened twenty years ago by Thomas Jackson, ${ }^{11}$ who provided an argument in favor of the automatic stay of creditors' individual claims. Jackson wrote that the multiplicity of creditors and their alternance in time which normally characterizes the financial structure of enterprises at the moment of their insolvency may induce its ordinary creditors to anticipate one another in a costly zero-sum game. A collective bankruptcy would allow to coordinate ordinary creditors' claims by distributing the debtor's unencumbered assets in proportion to the amount due to each ordinary creditor.

market participants are penalized by the markets if they make bad decisions (they lose money), and rewarded for making good decisions (they make money), a market player has a strong incentive to make wise business decisions. By contrast, since a bankruptcy judge does not have a personal stake in the firm, she does not bear the consequences of any business decision made in the bankruptcy context."

${ }^{10}$ See also Harold Demsetz (1995), The Economics of the Business Firm, Cambridge University Press, p. 43-4 and Richard Posner, Economic Analysis of Law, $5^{\text {th }}$, Aspen Law \& Business, 1998, p. 439 who aver that the risk of bankruptcy is an incentive for managers to follow shareholders' will.

${ }^{11}$ Thomas H. Jackson, Bankruptcy, Non-Bankruptcy Entitlements, and the Creditors'Bargain, Yale Law Journal, vol. 91, pp. 857-907, 1982 
Jackson's argument has elicited several proposals aimed at singling out mechanisms to distribute debtors' assets without any waste of resources. These proposals are all aimed at distributing automatically, although in different ways, the insolvent debtors' assets to creditors, for instance through auction selling (which entails dissolving the insolvent enterprise's juridical identity) or by turning creditors into shareholders (which allows to cancel debt thereby maintaining the enterprise juridical identity). ${ }^{12}$

Other authors have contrasted Jackson's vision arguing that creditors and debtors are able to efficiently coordinate their interests by way of contract. ${ }^{13}$

Anyway, the different points of view in both camps share the necessity to recognize directive powers to creditors in bankruptcy and to give public authorities (judiciary and administrative) the role to ascertain the regularity of the procedures but not to direct them.

\subsection{The inadequacy of Italian legislation}

European legislations deal with the role of creditors in bankruptcy in very different ways. Nonetheless, in several cases creditors are given directive powers: among the solution chosen there are countries where the collective principle is rigidly applied (Sweden) and other countries who do not recognize the automatic stay of creditors (United Kingdom and Germany). ${ }^{14}$

\footnotetext{
${ }^{12}$ See for instance Douglas Baird, The Uneasy Case for Corporate Reorganization, Journal of Legal Studies, vol. 15, p. 127ff., 1986; L. Bebchuk, A New Approach to Corporate Reorganization, Harvard Law Review, p. 775-804, 1988; P. Aghion, O. Hart and J. Moore, The Economics of Bankruptcy Reform, Journal of Law, Economics and Organization, vol. 8, p. 523-46, 1992; M. Bradley and M. Rosenzweig, The Untenable Case for Chapter 11, Yale Law Journal vol. 101, p. 1043 ss., 1992; Barry Adler, Financial and Political Theories of American Corporate Bankruptcy, Stanford Law Review, vol. 45, p. 311 ss., 1993; Oliver Hart, Different Approaches to Bankruptcy, 2000, http://www.nber.org/papers/w7921.

${ }^{13}$ See J. W. Bowers, Groping and Coping in the Shadow of Murphy's Law: Bankruptcy Theory and the Elementary Economics of Failure, Michigan Law Review, vol. 88, p. 2097-2150, 1990; R. K. Rasmussen, Debtor's Choice: A Menu Approach to Corporate Bankruptcy, Texas Law Review, vol. 71, p. 51-121, 1992; R. K. Rasmussen and D. A. Skeel, The Economic Analysis of Corporate Bankruptcy Law, American Bankruptcy Institute Law Review, vol. 3, p. 85-115, 1995; Alan Schwartz, The Law and Economics Approach to Corporate Bankruptcy, in "Faillite et concordat judiciaire: un droit aux contours incertains et aux interférences multiples", proceedings of the conference held in Louvain-la-Neuve (Belgium) on 25 and 26 avril 2002, Bruxelles, Bruylant, p. 243-73, 2002. Schwartz also demonstrates that it is possible for creditors to "bribe" debtor companies' administrators not to prevent its liquidation in case of insolvency.

${ }^{14}$ See Paolo Santella, Le procedure fallimentari in Italia e in Europa e il costo dei rimedi giuridici del credito bancario, Bancaria, December 2002.
} 
It is open to debate which of these systems is preferable in ensuring the best coordination of creditors' interests, as well as whether and to what extent the law might integrate the contractual activity of creditors and debtors in order to facilitate the financial restructuring of ailing enterprises. ${ }^{15}$ Anyway, since the characteristic of the Italian system is to deny any directive role for creditors (who may, under the provisions of the liquidation procedure introduced by 1942 bankruptcy act and the financial restructuring procedure introduce by the 1999 extraordinary administration act, just express non-binding opinions) ${ }^{16}$ the main goal of a bankruptcy reform in Italy should be, before solving the problem of their coordination, to guarantee creditors credible powers of deterrence vis-à-vis insolvent debtors.

\subsection{The costs of the inefficiency of bankruptcy legislation}

In the end, the debtor enterprises ultimately bear the cost of an inefficient bankruptcy legislation, at least from two points of view.

In the first place, it is logic to assume that the subordination of creditors be reflected on the working of the credit system, since banking creditors have the interest and the possibility to transfer to the debtors the costs of bankruptcy legislation, first of all in the form of higher interest rates but presumably also through other forms of self protection such as credit rationing, multiple creditors, lower average credit length or amount.

In the second place, the price inflicted by the inefficiencies of bankruptcy legislation on debtor enterprises may translate itself not just in a higher cost of credit, but also in a deficient monitoring on debtor enterprises on the part of creditors. According to not just Berle and Means ${ }^{17}$ and Galbraith ${ }^{18}$, but also Schumpeter in his Capitalism, Socialism and Democracy, ${ }^{19}$ an inefficient monitoring of managers by shareholders represents a very serious danger for

\footnotetext{
${ }^{15}$ The reference on this point is of course the American Chapter 11 procedure, for a first introduction to which see L. A. Bebchuk, Chapter 11, in The New Palgrave Dictionary of Economics and the Law, vol. I, London, Macmillan, 1998 p. 219-24.

${ }^{16}$ See Paolo Santella, Alcune considerazioni su soluzioni alternative in tema di fallimento, La rivista del diritto commerciale, n. 3-4/5-6, 2002. It is important to signal that in Italy these problems are made even more serious by the extraordinary length of bankruptcy procedures and by the obstacles that bankruptcy legislation poses to the negotiating activity of creditors and debtors aimed at preventing insolvency.

${ }^{17}$ Berle, A., and G. Means (1933)

${ }^{18}$ J. K. Galbraith (1967), The New Industrial State, Boston, Houghton Mifflin

${ }^{19}$ Joseph A. Schumpeter (1942), Capitalism, Socialism and Democracy, Harper \& Brothers.
} 
the western economic system, whose enterprises could run the risk of being managed by managers-bureaucrats irresponsible to their shareholders. On this point, even though further researches have showed the efficiency of company law to allow shareholders to monitor management, ${ }^{20}$ the prompt reactions which take place periodically following episodes of corporate mismanagement are proof of the full conscience in western countries of the importance that managers be faithful executors of the shareholders' will. ${ }^{21}$

More recently, the growing importance of debt capital on the total assets of modern business enterprises has brought to attention the other part of corporate governance, that is monitoring by creditors on debtor companies' management. In this case the debate focuses on whether bankruptcy legislation allows creditors to sanction those debtors who do not respect credit contracts. Due to the poor credibility of sanctioning instruments, enterprises might suffer from lack of control on management proportional to their recourse to credit. $^{22}$

For these reasons it should be recognized that, in countries where creditors do not have directive powers in bankruptcy, the reform of bankruptcy legislation is one of the most important structural reforms.

\footnotetext{
${ }^{20}$ See the proceedings of the conference "Corporations and Private Property" published by the Journal of Law and Economics, June 1983, with contributions by George Stigler, Douglass North, Eugene Fama and Michael Jensen, Oliver Williamson and Harold Demsetz; See also the comparative study by La Porta R., F. Lopez-de Silans, A. Shleifer and R. Vishny, Law and Finance, Journal of Political Economy, vol. 106, m. 6, p. 1113-55, 1998 in which the authors show that US and other Anglo-Saxon legal system allow for efficient management monitoring even in fragmented ownership structures.

${ }^{21}$ This of course does not mean that there are no changes to be made in corporate law. For surveys on the main issues on discussion, see for instance A. Shleifer and R. Vishny, A Survey of Corporate Governance, Journal of Finance, vol. 52, n. 2, 1997; D. K. Denis and J. J. McConnell, International Corporate Governance, 2003, mimeo.

${ }^{22}$ There have been in the last years several studies on the characteristics of bankruptcy around the world, see for instance Lopez-de-Silanes, F., A. Shleifer and R. Vishny, Legal Determinants of External Finance, Journal of Finance, vol. 52, n. 2, 1997; La Porta, R., F. Lopez-de-Silanes, A. Shleifer and R. Vishny, Law and Finance, Journal of Political Economy, December 1998. Waiting for systematic studies on the relationship between economic growth and bankruptcy, Bergoeing, R., P. J. Kehoe, T. J. Kehoe and R. Soto, Decades Lost and Found: Mexico and Chile Since 1980, Federal Reserve Bank of Minneapolis Quarterly Review, vol. 26, n. 1, p. 3-30, 2002, single out the introduction of directive powers for creditors (together with privatization of state-owned assets) as the reason for the high rate of economic growth in Chile in the period 1980-2000.
} 


\subsection{Conclusion}

Whenever bankruptcy legislation cannot guarantee the possibility for creditors to recover their credits from insolvent debtors, the working of an economic system based on private property may be impaired.

Furthermore, whenever the threat of bankruptcy does not exert credible deterrence on debtors, the possibility for creditors to monitor the management of debtor enterprises may be impaired. In proportion to the importance of debt on total assets, enterprises are at risk of being managed inefficiently by managers who have power without responsibility.

In countries where bankruptcy legislation already gives directive powers to creditors, the attention should be focused on singling out procedures to coordinate their action; on the other hand, where, as in Italy, creditors have no directive powers in bankruptcy, that debate should wait for the introduction of such powers. 



\section{A rating method for bankruptcy legislations}

In this chapter, with reference to five European countries (Sweden, United Kingdom, Germany, France and Italy), we examine the cost for banking creditors of bankruptcy procedures (2.1) according either to the powers banking creditors and the time of recovery of credits. As for the former, Italy and France do not recognize any directive role to creditors, just the authority to deliver non-binding opinions to the court. Furthermore, especially in countries where creditors do not have directive powers in bankruptcy, an accessory interpretative tool is represented by the length of the procedures, which contributes to make the threat of bankruptcy less credible.

The chapter then goes on to examine (2.2) the other forms of recovery of banking credit, that is free covenants (made more difficult in Italy and France by certain provisions of bankruptcy legislation) and enforcement proceedings, whose length is significantly different among the considered countries.

\subsection{Bankruptcy procedures according to creditors' protection and length}

In this section we examine bankruptcy procedures according to the degree of creditors' protection and the length of the procedures.

\section{a) Sweden}

According to the main bankruptcy procedure (Konkurslagen) ${ }^{23}$ from the declaration of bankruptcy ${ }^{24}$ ensues that the management of the debtor's assets is entrusted to the trustee, who must take all the measures necessary to achieve a favourable and rapid winding-up so as to distribute its proceedings

\footnotetext{
${ }^{23}$ The other existing procedure (Ackordslagen) is rarely applied (50 cases out of 9000 every year according to Mimeo 1999, p. 31), and it is aimed at preventing insolvency. See on this point Strömberg 2000, p. 2645, who attributes the causes of its inefficiency to (i) the necessity that the restructuring plan provide an entire reimbursement for preferential creditors and at least $25 \%$ to ordinary creditors; (ii) the impossibility to give new creditors precedence over preferential creditors; (iii) the impossibility to apply to this procedure some provisions concerning state-funded employee protection measures which apply in case of insolvency.

${ }^{24}$ Creditors who wish to request the opening of the procedure must prove the state of insolvency (the Swedish legislation defines insolvency as the temporary inability for the debtor to pay its debts).
} 
to the creditors according to their priority. ${ }^{25}$ The trustee must not necessarily liquidate the debtor's assets piecemeal: when it is in the creditors' interest, he may sell all the assets as a going concern. It is what happens in the majority of cases, thing which guarantees a particular celerity to the entire procedure. ${ }^{26}$ From the declaration of bankruptcy ensues the impossibility for preferential and non-preferential creditors $^{27}$ to make recourse to individual legal proceedings against the debtor's estate. Only the trustee is allowed to sell the debtor's assets. ${ }^{28}$ On the other hand, creditors have an important role in bankruptcy processes, particularly as regards monitoring the trustee. Although the trustee is nominated by the court, she is monitored by an inspector nominated by the creditors who, in the case they are not satisfied with the trustee's administration, may ask the court to appoint a new trustee. Besides, the trustee needs the consent of creditors holding security in real property and personal property before selling such property. ${ }^{29}$

Several provisions make sure bankruptcy proceedings are short, in particular creditors' monitoring powers on the trustee, the low degree of bureaucracy of the procedure ${ }^{30}$ and, as we have seen, the wide range of solutions to which the trustee may make recourse so as to liquidate the bankrupt enterprise's assets. Furthermore, the trustee has an interest in closing the procedure in a short time, since he is the sole responsible for the management of the bankrupt's assets ${ }^{31}$ so that he is responsible to the creditors in case of negligence.

\footnotetext{
${ }^{25}$ The trustee must obtain the consent of creditors holding security in real property before selling such property (see Swarting (2002))

${ }^{26}$ Strömberg (2000), p. 2647, reports for these cases an average length of the procedure of 2-3 months. Strömberg and Thornburn (1996) estimate the average cost of insolvency procedures in Sweden at $19.4 \%$ of the debtor's assets.

${ }^{27}$ With the exception of the retention of title and leasing. The Swedish law considers among preferential creditors also those creditors entitled with a floating charge. The floating charge is a security interest in the changing assets of a business enterprise. Different from the situation in the UK, the creditor entitled with a floating charge may not appoint a receiver, who under the Swedish law must act in the interest of all creditors. See Galanti (2000).

${ }^{28}$ See Åbjörnsson (2002), p. 116.

${ }^{29}$ Swarting (2002), p. 261.

${ }^{30}$ For instance, only in a minority of cases do the creditors need to file proofs of debt with the court. In the majority of cases the trustee alone administers the winding up of the estate (cf. Swarting (2002), p. 261).

${ }^{31}$ The role of the court is limited to approving the distribution to creditors of the proceedings of the liquidation of the debtor's estate.
} 


\section{b) The United Kingdom}

Bankruptcy legislation in the UK traditionally gives a directive role to creditors either in the liquidation procedure ${ }^{32}$ and in the main reorganization procedure, Receivership. ${ }^{33}$

In Receivership floating-charge creditors are entitled ${ }^{34}$ to nominate a trustee (receiver) to manage the insolvent debtor enterprise. The task of the receiver is to manage the debtor company so as to satisfy the floating charge creditors. The receiver may choose between liquidating the debtor's estate piecemeal and selling the entire business to a third part. In the performance of these duties he may not violate the rights of legal priority creditors and fixed-charge creditors. Receivership does not prevent other creditors (non-preferential creditors) to apply for the liquidation of the company. In that case, they may appoint a trustee to monitor the receiver and to manage the debtor's assets left after floating-charge creditors have been satisfied..$^{35}$

The characteristic of the Receivership is to allow to safeguard viable assets in financially troubled companies without necessarily guaranteeing the survival of the enterprise in its legal identity. Since the receiver's task is to liquidate at the best possible terms some or all the debtor's assets, normally the extinction of the debtor company ensues. ${ }^{36}$ Because of the fixed costs required, the receivership procedure is used to deal with the insolvency of sizable companies. $^{37}$

${ }^{32}$ They are the Creditors Voluntary Liquidation and the Compulsory Liquidation.

${ }^{33}$ See Citron et al. (2002), p. 3, who report that, in the period $1992-1998,85 \%$ of the insolvency procedures were liquidation procedures (compulsory liquidation or creditor voluntary liquidation) and $12 \%$ Receivership.

${ }^{34}$ Without asking for the authorization from the court or from other creditors.

${ }^{35}$ This explains why creditors entitled with floating charge usually request also fixed charges. See in this respect Citron et al. (2002), p. 3: "In practice, creditors usually ensure they hold both floating and fixed charges, the former to give the right of appointment of administrative receiver and the latter to gain priority over certain assets realisations."

${ }^{36}$ The Receivership constitutes the bulk of the restructuring procedures commonly used. Scarcely applied is the other restructuring procedure, the Company Voluntary Arrangement, which consists of the approval by the majority of creditors of a reorganisation plan submitted by the trustee in charge of the Administration. The latter procedure has been introduced by the 1986 Insolvency Act, which gives the court the power to appoint a trustee who must take care of the rights of all creditors, not just of the creditors entitled with the floating charge. At least until 2002 the Administration was severely limited by the Receivership: on the one hand, the Administration could not be initiated during Receivership; on the other hand, creditors entitled with Floating Charge could initiate the Administration even after the opening of the Receivership. On 9 November 2002 the new Enterprise Act obtained the Royal Assent. It provides, among other things, several limitations to the possibility for creditors entitled with Floating Charge to nominate an administrative receiver. For an introduction to the new Enterprise Act see Shandro (2002) and Rajak (2003).

${ }^{37}$ See Franks and Sussman (2000), p. 19. 
In the case of liquidation procedures, the court appoints a trustee to liquidate the insolvent enterprise. The trustee represents all the creditors, not just the preferential ones. On the other hand, even though liquidation takes places formally under the court's supervision, the procedure is influenced by creditors as well, who take into consideration its lesser administrative costs. Since floating-charge creditors may in fact decide whether to allow the liquidation procedure to take place or to start receivership, they decide on their course upon balancing the possible higher recovery rate guaranteed by receivership with liquidation's lower administrative costs. ${ }^{38}$

\section{c) Germany}

According to bankruptcy legislation in force until 1999 there was a radical difference between preferential and non-preferential creditors. While the former could make recourse to individual legal proceedings against the debtor's estate even after the declaration of bankruptcy, for the duration of insolvency proceedings (Konkursordnung) the latter could not enforce their claims. Following the opening of the procedure the management of the insolvency estate passed to a court-appointed trustee (Konkursverwalter), upon whom creditors had monitoring powers. Even though the task of the trustee was to liquidate the bankruptcy estate and to distribute its proceedings to non-preferential creditors, she could temporarily continue to run the debtor's business waiting for better market conditions. On the other hand, in the majority of cases the collective procedure was made impossible by the selling by the preferential creditors of the secured goods and the consequent closing of the procedure due to lack of assets left. ${ }^{39}$

The reform of bankruptcy legislation which became effective as of 1 st January 1999 introduced measures aimed at keeping in business ailing enterprises by means of partially and temporarily preventing preferential creditors to enforce their claims. The new legislation now requires that preferential creditors' right to seize the debtor's assets is suspended for three months so as to promote a reorganization of the insolvent business. It is now possible for a trustee (who can be nominated by the creditors) to present a reorganization plan which must be approved by each class of creditors. A class of creditors accepts the plan if a majority in number and amount in

\footnotetext{
${ }^{38}$ See Franks and Sussman (2000), p. 19.

${ }^{39}$ Franks, Nyborg and Torous (1996), p. 92-3, who report that in 1992 this happened in $92 \%$ of cases
} 
that class vote in favor. ${ }^{40}$ The plan may provide for the liquidation of the debtor's assets and the dissolution of the enterprise in its juridical identity or alternatively its conservation. It may also provide the suspension or the renunciation of the preferential creditors' rights. It is still to be evaluated, given the short interval elapsed since the introduction of the reform, whether in practice the reform has actually introduced a significant restriction of creditors' powers. ${ }^{41}$

\section{d) France}

French bankruptcy legislation's ${ }^{42}$ distinctive feature is to attribute the majority of powers to courts at the expenses of creditors. Bankruptcy legislation, as amended in 1994 provides a reorganization procedure called Redressement judiciaire which gives the court the right to initiate, whenever redressing is not "manifestly impossible", an observation period between 6 and 20 months, during which the insolvent enterprise is managed under the court's supervision. ${ }^{43}$ At the end of the observation period the court may decide the liquidation of the enterprise or it can cram on all creditors a reorganization plan. The reorganization plan is adopted even without the consent of the creditors and the debtor alike. It can provide a restructuring of the debt payments or even a partial cancellation of the debt. ${ }^{44}$ The plan may last up to 10 years (15 in the case of agricultural firms). During the entire length of the procedure creditors may not enforce their claims. ${ }^{45}$

\footnotetext{
${ }^{40}$ Ordinary and preferential creditors must vote in separate classes; the plan must be approved by each class by simple majority (number of creditors and amount of credits). Furthermore, the court must ascertain that the plan does not provide for any creditor worse terms than in absence of a plan. If this condition applies, the court may approve the plan even against the advice of one class of creditors.

${ }^{41}$ For a first commentary see Wihlborg, C. and S. Gangopadhyay, Infrastructure Requirements in the Area of Bankruptcy Law, Brookings-Wharton Papers on Financial Services, 2001, p. 18, according to whom the reform would not have changed the essential features of German insolvency legislation.

${ }^{2}$ Loi 148 du 1er mars 1984 sur la prévention et le règlement amiable des difficultés des entreprises and loi n. 98 du 25 janvier 1985 sur le redressement et liquidation judiciaire des entreprises; both acts have been amended by the loi n. 475 du 10 juin 1994.

${ }^{43}$ Through a trustee. During this period the directors of the debtor enterprise keep their powers concerning the ordinary management of the enterprise, and they may be authorized by the court to act outside the ordinary management (article 33 of the law).

${ }^{44}$ Moody's (2000a), p. 10.

${ }^{45}$ French legislation also provides a procedure aimed at preventing insolvency (Règlement amiable) which may be started in the presence of difficulties which have not turned into insolvency yet. The Règlement amiable, was originally introduced in 1984 but it was very rarely applied. The 1994 reform amended this procedure by giving more power to the court and by introducing the possibility to the debtor to stop payments in order to prepare a reorganization plan. Nonetheless, the procedure has kept its main feature of being conditioned to the voluntary approval by all creditors and it has continued to be very rarely used.
} 
French bankruptcy legislation's main goals are in the first place the conservation of the enterprise and the protection of the firm's employees; creditors' rights are considered in a subordinate order. To this end, the procedure gives directive powers to the court, while creditors are entitled merely with consultative powers. ${ }^{46}$

Since the reorganization procedures only in a minority of cases ended successfully, ${ }^{47}$ in the course of the last decade the French legislator has gradually come to accept the principle of limiting reorganization procedures to those cases in which reorganization is concretely feasible. The 1994 reform has introduced a preliminary scrutiny on the part of the court so as to allow the immediate liquidation of non viable enterprises. Following the reform, the percentage of immediate liquidations has reached in 1999 about $70 \%$ of total liquidations and about $65 \%$ of total bankruptcy procedures. ${ }^{48}$

\section{e) Italy $^{49}$}

just as in France, even in Italy bankruptcy procedures ${ }^{50}$ distinctive feature is the marginal role of creditors and the concentration of powers on the court and the administrative authorities: ${ }^{51}$

- liquidation. ${ }^{52}$ The procedure gives the court the power of administration, direction, and control, while the role of creditors is purely consultative. ${ }^{53}$ Following the starting of the procedure, creditors lose the right to enforce their claims individually, and every power relative to their rights against the debtor passes to the court. as for the debtor, she not just loses the power

\footnotetext{
${ }^{46}$ Moody's (2000a), p. 1.

${ }^{47}$ According to a recent parliamentary report (Office parlementaire d'évaluation de la législation, Rapport sur la législation applicable en matière de prévention et de traitement des difficultés des entreprises, committee chaired by senator Jean-Jacques Hyest, 5 December 2001, p. 8), all over the 1990 s the procedure ended in liquidation in $90 \%$ of cases.

${ }^{48}$ Ibid., p. 50.

${ }^{49}$ For an analytical illustration of the Italian insolvency legislation see G.U. Tedeschi (2001), Manuale di diritto fallimentare, Cedam, Padova, A. Maffei Alberti, (2000) Commentario breve alla legge fallimentare, $\mathrm{IV}^{\wedge}$ edizione, Cedam, Padova, and V. Buonocore (1999), Manuale di diritto commerciale, Torino, Giappichelli. For a treatment in English see Cappiello (2002).

${ }^{50}$ With the exception of the deed of arrangement, which is anyway rarely used.

${ }^{51}$ See Libonati (2001), p. 328.

${ }^{52}$ Royal decree 16 March 1942 n. 267.

${ }^{53}$ Creditors are represented in the procedure through the creditors committee, whose members are appointed by the court. The function of the committee is not to represent the interest of creditors but "the public interest and the sum of the private interests involved in the procedure" (Maffei Alberti (2000), p. 151). In practice, the same author underlines that "the importance of the creditor committee is almost non-existent". See also Buonocore (1999), p. 1166.
} 
to manage the enterprise, but she also falls victim to a number of automatic sanctions provided by the procedure..$^{54}$;

- Deed of arrangement (Concordato preventivo). It is scarcely applied, owing to its restrictive requirements. ${ }^{55}$

- Special administration (Nuova legge Prodi ${ }^{56}$ ). The procedure is managed by the court and by the administrative authority and it applies to large companies. ${ }^{57}$ The procedure is conditioned to the existence of actual possibilities of economic recovery. This goal may be pursued either through the financial reorganization of the enterprise or through the selling to third parties the entire firm's assets. When it was introduced, the "Prodi Law" was aimed at rescuing every insolvent enterprise which fell under its scope. After years of unsuccessful implementation ${ }^{58}$ the law has been reformed because of its incompatibility with the European legislation on state aids. ${ }^{59}$ The 1999 special administration act now provides that the procedure applies only where there are actual possibilities of recovery. The procedure is aimed at the adoption of a reorganization plan or alternatively at the liquidation of the enterprise's assets. Now the procedure is divided in two parts. In the first part a trustee appointed by the court relates the court on the possibility of economic recovery, following which the court either proceeds to liquidating the company ${ }^{60}$ or to the reorganization procedure. In the latter case company is managed by one or, alternatively, three trustees appointed by the Minister of Industry, who submits to the Minister a reorganization plan providing either the liquidation of the company's assets or the restructuring of the company. For the entire length of the procedure non creditors may not enforce their claims.

\section{$* * *$}

54 Among these are the prohibition to have access to the personal correspondence, the prohibition to leave her residence without permission from the court, the prohibition to be appointed director in a corporation, to concur for a public procurement, and the prohibition to vote for five years. See Panzani (2001), p. 129.

${ }^{55}$ The deed of arrangement must provide to pay ordinary creditors at least $40 \%$ of their credits. See Jorio (1999), p. 759.

${ }^{56}$ Legislative decree 8 July 1999, n. 270, which has replaced the "Prodi Act" n. 95 of 3 April 1979.

${ }^{57}$ These are identified, among other things, by the following conditions: (i) at least 200 employees; (ii) total debt at least two thirds of total assets and two thirds of financial turnover.

${ }^{58}$ See Alessi (1998), p. 113.

${ }^{59}$ The European Commission opened in 1997 a sanctioning procedure against the law 95 of 1979 in its entirety and several decision on specific points (see in this last respect the decisions 96/434/CE, 96/515/CECA and 97/754/CECA). Even the ECJ recognized the Prodi Act in breach of the European legislation on state aid (ruling 1 December 1998, Ecotrade srl vs. Altiforni e Ferriere di Servola spa). For a general treatment of this subject see Cirenei (1999).

${ }^{60}$ See Gambino (2000), p. 5. 
From the preceding illustration notable differences emerge among the powers of creditors in bankruptcy in the European countries considered and the length of the procedures (Table A, first and second columns). The main observation is that bankruptcy legislations which derive from Napoleonic codification (France and Italy) do not guarantee credible sanctions to creditors, who are deprived of directive powers at behest of courts and administrative authorities. In the other countries (United Kingdom, Sweden, Germany before 1999) creditors have directive powers in the procedure, while these powers are in part attenuated in the new German legislation. Swedish bankruptcy legislation shares several aspects with Germany and Britain, since it recognizes creditors monitoring powers on the trustee and it guarantees a fast liquidation of insolvent companies. ${ }^{61}$ While in the United Kingdom and in Germany (until 1999) preferential creditors may directly enforce their claims, in Sweden (and in Germany since 1999) their claims are channeled through a collective procedure. ${ }^{62}$ On the other hand, even in Sweden the wide powers of control creditors have on the trustees and the simplicity of the procedure make it possible for creditors to have a directive role in liquidating the insolvent company's assets. More powers are recognized to the court by the new German legislation, although its directive powers are still at the hands of creditors. ${ }^{63}$

The length of the procedure may be considered as a complementary indicator of the cost of bankruptcy procedures for creditors, in particular whenever the latter are deprived of directive powers in the procedure. From available data it is clear that Italian and French creditors not only can not manage the liquidation of their insolvent creditors' assets, but also they must wait a sizable length of time before receiving their share of whatever the court-appointed trustee has eventually managed to recover or, in a minority of cases, before the financial reorganization of the debtor takes place. From this point of view a positive signal comes from France, where the 1994 reform has reduced the length of a notable percentage of liquidation procedures.

${ }^{61}$ See Strömberg (2000), p. 2645.

${ }^{62}$ See Moody's (2000b), p. 9: "There is less extensive involvement by the courts both in pre- and post-insolvency procedures in Germany as compared to France, albeit the courts have certain important powers that can influence the outcome of proceedings for creditors and the debtor. As under the UK regime, the role of the court in an insolvency proceeding depends on the particular insolvency proceeding involved. In general and in practice the insolvency court in Germany takes a supervisory role in proceedings and often relies on the recommendations of the insolvency administrator and creditors' committee... a creditor in Germany (particularly a senior secured creditor) is in a good position relative to other European jurisdictions...the practical influence of the creditor to drive restructuring and influence the future of the debtor in Germany is considerably greater than compared to France where the court is extremely pervasive."

${ }^{63}$ See P. R.Wood (1995), Principles of International Insolvency, Sweet \& Maxwell. 
As for the percentage of credits recovered, available data ${ }^{64}$ confirm the conclusions expressed in the previous paragraphs: on the one hand in Italy preferential creditors ${ }^{65}$ recover a very low percentage of their credits $(33 \%)^{66}$; on the other hand much higher percentages characterize United Kingdom, Netherlands and Sweden.

An additional confirmation comes from a study conducted by Isae on the efficiency of justice in Europe. ${ }^{67}$ The study compares the average length of civil procedure in several European countries. Although bankruptcy procedures are not present in the sample, such data (table A, third column) represent an indirect indicator of the efficiency of bankruptcy procedures.

The conclusions on the cost of bankruptcy procedures for creditors are synthesized in the last column of table $\mathbf{A}$, in which French and Italian creditors suffer from a higher cost of recourse to bankruptcy procedures compared to the other three countries considered.

\section{Table A}

\section{LEGAL COST OF BANKRUPTCY FOR BANKING CREDITORS ${ }^{68}$}

\begin{tabular}{|c|c|c|c|c|}
\hline & $\begin{array}{c}\text { Banking creditors' } \\
\text { powers in } \\
\text { bankruptcy } \\
\end{array}$ & $\begin{array}{c}\text { Bankruptcy procedures' } \\
\text { Average length } \\
\text { (months) }\end{array}$ & $\begin{array}{c}\text { Average length } \\
\text { of civil procedures } \\
\text { (months) }^{69}\end{array}$ & $\begin{array}{c}\text { Legal cost of } \\
\text { bankruptcy for } \\
\text { banking creditors }\end{array}$ \\
\hline SWE & Directive & 12 & 48 & Low \\
\hline ENG & Directive & Less than 1 year & 52 & Low \\
\hline GER & Directive & $12 / 27$ (old procedure) $^{70}$ & 50 & Low (average-low ${ }^{71}$ ) \\
\hline FRA & Consultative & $24-36$ & 89 & High (average-low ${ }^{72}$ ) \\
\hline ITA & Consultative & 72 & 116 & High \\
\hline
\end{tabular}

${ }^{64}$ Quoted by Bianco-Marcucci (2001).

${ }^{65}$ Banks in the first place.

${ }^{66}$ This is confirmed by a study of the Italian central bank (Banca d'Italia (2002b)), which reports average recovery rates of $27 \%$ for insolvency procedures and $36 \%$ for deeds of arrangements.

${ }^{67}$ Institute for Studies and Economic Analyses (ISAE), (2001).

68 Sources: for Sweden, Mimeo (1999); for the UK, Germany, France and Italy, Bianco-Marcucci (2001); for the UK and Germany (length of the procedures) Franks, Nyborg and Torous (1996).

${ }^{69}$ Source: ISAE (2001).

${ }^{70}$ The procedure did not involve preferential creditors, who could reclaim their credits directly and individually. For this reason the procedure applied only to $25 \%$ of cases; in the other $75 \%$, the procedure was closed for lack of assets (Kamlah (1996)).

${ }^{71}$ After the 1999 reform.

${ }^{72}$ After the 1994 reform, which allowed to reduce the length of the liquidation procedure. 


\subsection{Other relevant factors: obstacles to the conclusion of direct agreements between creditors and debtor and cost of enforcement proceedings.}

Bankruptcy legislation is not the only possible form of credit recovery: contractual agreements between debtor and creditors allow to prevent insolvency; enforcement proceedings allow preferential creditors to enforce their claims on the debtor's assets. ${ }^{73}$

\section{Contractual agreements}

Different from the other countries considered, in France and in Italy bankruptcy legislation hinders the conclusion of contractual agreements between creditors and their debtor aimed at preventing insolvency. In France, such agreements are discouraged by the protection of the debtor in bankruptcy. ${ }^{74}$ Further, contractual guarantees provided by creditors may be declared void in case of ensuing bankruptcy whenever they are given during the so-called "suspect period". ${ }^{75}$ Finally, such agreements are discouraged by the possibility that creditors be accused, in case of ensuing insolvency, of having failed to timely denounce their debtor's insolvency ${ }^{76}$ In Italy, several provisions of 1942 bankruptcy act discourage creditors from contractually negotiating financial restructuring with the debtor, first of all art. 67 and article 217 of the bankruptcy act which sanction those creditors who failed to denounce their debtors' insolvency. ${ }^{77}$

\section{Cost of enforcement proceedings}

Djankov et als. (2001) compare the average length of time necessary for creditors to enforce their claims in case of unpaid checks. These data may be used as an indicator of the efficiency of the procedures of individual

\footnotetext{
${ }^{73}$ On the percentages of credit recovery according to the various procedures, see for Italy Banca d'Italia (2002b), p. 4-10. S. Claessens and L. F. Klapper, Bankruptcy Around the World: Explanation of its Relative Use, World Bank Policy Research Working Paper 2865, July 2002, observe that the incentives of creditors to make recourse to insolvency procedures rather than to informal workouts depend, according to mechanisms not entirely clear, from the characteristics of insolvency procedures. What seems clear is that, other things fixed, the inefficiency of the legal system is an incentive to make recourse to informal workouts (see on this point also M. Bianco and S. Chiri, Le partecipazioni bancarie nelle imprese in Italia: investimenti e ristrutturazioni finanziarie, in Banca, Impresa, Società, n. 3, 1997, pp. 393-426).

${ }^{74}$ This both in case of Règlement amiable and of Redressement judiciaire. In the latter case, the entrepreneur is reintegrated at the wheel of the company in the case the court approves the restructuring plan.

${ }^{75}$ The suspect period may last up to 18 months.

${ }^{76}$ Moody's (2000a), p. 8.

${ }^{77}$ See Rossi (1996), p. 324.
} 
execution. Taking out from the study the data relative to the five countries here considered (table B, first column) allows to show the great inefficiency of Italian procedures compared to the other countries'.

Another indicator on enforcement proceedings is given by the procedures concerning charges on real property (table B, second column).$^{78}$ In the United Kingdom in case of default on debt, fixed-charge creditors have the right to appoint a trustee to have the designated property sold and the proceeds applied to discharge the debt. ${ }^{79}$ In Germany, creditors secured by charges on real estate must ask the court to have the designated property sold. The security over real property can only be enforced by a compulsory sale through public auction or by sequestration upon an executory title. The enforcement of the mortgage requires the intervention of the court and is usually carried out by public auction. ${ }^{80}$ Even in France and in Italy it is necessary for creditors to ask the intervention of the court to proceed to the compulsory sale of the designated property. The average length of the procedure in France is between two and three years, while in Italy it is between five and nine years. ${ }^{81}$

Table B

LENGTH OF ENFORCEMENT PROCEEDINGS

\begin{tabular}{|l|c|c|}
\hline & $\begin{array}{c}\text { Enforcement proceedings for } \\
\text { unpaid checks (days) }^{82}\end{array}$ & $\begin{array}{c}\text { Enforcement proceedings for } \\
\text { charges on real property (years) }^{83}\end{array}$ \\
\hline SWE & 190 & n/a \\
\hline ENG & 101 & Creditors-appointed trustee \\
\hline GER & 154 & Court-appointed trustee (same as in ITA and FRA) \\
\hline FRA & 181 & $2-3$ \\
\hline ITA & 645 & $5-9$ \\
\hline
\end{tabular}

${ }^{78}$ See Moody's (2000a), (2000b), (2000c), (2001).

${ }^{79}$ Shandro (2002), p. 87.

${ }^{80}$ Moody's (2000c), p. 17.

${ }^{81}$ See Moody's (2001), p. 14: "Despite amending legislation and introducing new initiatives, the Italian enforcement procedure for property can be lengthy. A few years may be expected to elapse before the mortgagee successfully obtains the sale of the property... As a matter of practice, the overall length of the procedure may vary significantly between regions. For example, a procedure to enforce a mortgage loan may take on average from a minimum of 5 years to a maximum of 9 years. It is not uncommon however, for a lender to be satisfied within 1-3 years."

${ }^{82}$ Source: Djankov et al. (2001).

${ }^{83}$ Source: Moody's (2000a) and (2001). 


\subsection{Conclusion}

In table $\mathbf{C}$ are reproduced synthetic evaluations of the cost for banking creditors of the different forms of credit recovery, that is, bankruptcy procedures, contractual agreements, and enforcement proceedings. The different degree of efficiency which each country shows corresponds to higher or lower legal costs to credit recovery by banks. In particular, with regard to the central-European and the Scandinavian countries considered, it is significantly more difficult for French and Italian bankers to enforce their claims following debtors' default. It is logical to assume that these difficulties may translate themselves in higher credit cost. ${ }^{84}$

Table C

COST OF BANKING - CREDIT RECOVERY

\begin{tabular}{|c|c|c|c|}
\hline & $\begin{array}{l}\text { Bankruptcy } \\
\text { procedures }\end{array}$ & $\begin{array}{l}\text { Contractual } \\
\text { agreements }\end{array}$ & $\begin{array}{l}\text { Enforcement } \\
\text { proceedings }\end{array}$ \\
\hline SWE & Low & Low & $\mathrm{N} / \mathrm{A}$ \\
\hline ENG & Low & Low & Low \\
\hline GER & Low (average-low ${ }^{85}$ ) & Low & Average-high \\
\hline FRA & High (average-high ${ }^{86}$ ) & Average-high & Average-high \\
\hline ITA & high & High & High \\
\hline
\end{tabular}

${ }^{84}$ See Zadra (2001), pp. 188-9.

${ }^{85}$ After the reform which came in force in 1999.

${ }^{86}$ After the reform which came in force in 1994. 


\section{A Basel II - based quantitative application to bankruptcy in Italy}

\subsection{Insolvency costs: a review of literature}

The aim of this paragraph is to review the literature on bankruptcy costs. In this regard, the common approach so far, consists in estimating the cost of insolvency law by looking at the balance sheet of those enterprises which are involved in some insolvency proceeding. As a result, according to this approach the cost of insolvency regulation is measured in terms of "accounting costs" which stem from the management of a firm in distress. There are two types of costs: direct costs and indirect costs. The former are referred to as the legal and other professional and administrative fees associated with the bankruptcy filing ${ }^{87}$ (that is to say measurable expenses arising specifically from an insolvency proceeding); the latter refer to non measurable expenses being met by a firm in distress such as lost sales, a decline in the value of inventory, increased operating costs, a reduction in the firm's competitiveness ${ }^{88}$ (that is to say a poorer performance that is specifically due to an insolvency proceeding).

The literature on bankruptcy $\operatorname{costs}^{89}$, then, can be classified according to two specific assumptions: a) a subjective assumption; b) an objective assumption . The former, defining what firms are eligible for measuring the cost of insolvency law, focuses on firms in financial distress. Instead, as far as the objective assumption is concerned, the unit of measure used to assess such an impact is represented by the costs ${ }^{90}$ being met by a distressed firm once a bankruptcy procedure has commenced.

${ }^{87}$ See. Weiss (1990).

${ }^{88}$ See. Weiss (1990).

${ }^{89}$ For a comprehensive selection of readings focusing on corporate bankruptcy see Bhandari J. S. and L. A. Weiss (eds), (1996).

${ }^{90} \mathrm{As}$ far as direct costs are concerned, they are easily measured; instead with regard to indirect costs, a proxy is needed. The latter are usually expressed as a percentage of a variable parameter such as the book value of total assets at the fiscal year-end prior to the bankruptcy filing, the liquidation value of the firms at the end of the bankruptcy process and the market value of equity. See later on this paragraph. 
Most of the literature estimating the direct costs related to distressed enterprises refers to the restructuring procedures envisaged under the rehabilitation chapter (Chapter 11) of the United States Bankruptcy Code. If attention is paid to the average direct costs measured in terms of the book value of total assets at the fiscal year-end prior to the bankruptcy filing, it could be worthwhile to see the works by Weiss (1990) and McMillan et al. $(1991)^{91}$.

Another approach within the measurement of direct costs takes into account the liquidation value of the firms at the end of the bankruptcy process. This method is used by Betker (1995) and McMillan et al. (1991) ${ }^{92}$.

Still regarding Chapter 11, some authors have focused on "prepackaged bankruptcies" that can be thought of as a "hybrid" form combining the advantages of two methods of reorganising troubled companies: workouts and bankruptcy ${ }^{93}$. According to Betker (1995) the average direct costs account for 2.85 per cent if compared with the book value of total assets at the fiscal year-end prior to the bankruptcy filing and for 3.23 per cent if compared to the liquidation value of the firms at the end of the bankruptcy process. The former relationship has been also estimated by Tashjian et al. $(1996)^{94}$.

Another research aimed at gauging direct costs of bankruptcy is made by White (1984): there, a comparison has been made of administrative costs to the total amount paid to creditors in samples both of firms that liquidated and firms that reorganised. According to a different method, Baird (1986) works out a cost estimate related to a firm going through a Chapter 11 procedure.

Turning from judicial rehabilitation to out-of-court rehabilitation, this field of research has been mainly surveyed by Gilson, John and Lang ${ }^{95}$ (1990), $\operatorname{Betker}^{96}$ (1995), Jensen $(1989,1991)$.

\footnotetext{
${ }^{91}$ According to them, the estimate ranges from 2.6 per cent (Weiss) to 5.4 per cent (McMillan et al.). The same approach is also maintained by White (1983) and Stanley and Girth (1971).

${ }^{92}$ In this regard, the average direct costs range from 6.3 per cent (Betker) to $23.5 \%$ (McMillan et al.).

${ }^{93}$ For an important paper on this subject see McConnel J. and H. Servaes, The Economics of pre-packaged bankruptcy: first appeared in McConnel J. and H. Servaes (1991) and then published in Bhandari J. S. and L. A. Weiss (eds), (1996).

${ }^{94}$ According to this research the average direct costs in terms of the value of assets of the last balance sheet approved amount to 1.85 per cent.

${ }^{95}$ This research refers to exchange offers.

${ }^{96}$ This research refers to exchange offers.
} 
Another important issue upon which much empirical research has been done is whether economies of scale occur in the event of a bankruptcy: do bankruptcy costs increase slowly when total assets are greater? Within the empirical evidence in favor of this connection there are works by Warner $(1977)^{97}$, Ang, Chua and McConnell (1982), McMillan et al. (1991), Betker $(1995)^{98}$. On the other hand, some doubt on this relationship is put forward by Weiss (1990) and Deis, Guffrey and Moore (1995).

Finally, as far as indirect costs are concerned, there have been a few efforts to measure them.

Among the main important research in this field there are the following: Altman (1984), Cutler and Summer (1988), White (1983), Baldwin and Mason (1993) and Opler and Titman (1994) ${ }^{99}$.

\subsection{Estimating the impact of insolvency regulation: a new approach}

The impact of any insolvency regulation has been mainly measured so far in terms of the costs being met by the distressed firms throughout the entire proceeding.

In fact, as seen previously above, the existing literature assesses bankruptcy costs by addressing the two assumptions as follows: a) the subjective assumption is meant to focus on the enterprises which are in financial distress; b) the objective assumption refers to those costs (either direct or indirect ones) incurred within such a state of distress.

From a different point of view, it could be maintained that any kind of firm can finance its operations by resorting to a combination of equity and credit. Regardless of the extent to which non-financial enterprises combine these sources of financing ${ }^{100}$, they borrow from commercial banks. Well, as far as banks are concerned, the most internationally active ones adhere to a financial

\footnotetext{
${ }^{97}$ In this research the magnitude of direct costs of bankruptcy is assessed by means of the market value of equity instead of the two other measures.

${ }^{98}$ The common rationale held by these works is that the higher the amount of assets of the corporate in distress the lower the direct costs due to the management of such a distress.

${ }^{99}$ Each of the three researches differ one another respectively in terms of the kind of firms, key variable as a proxy for indirect costs and time period.

${ }^{100}$ For an interesting research on this comparison, see Allen F and D. Gale (2000).
} 
regulation ${ }^{101}$ that is well suited to measure the impact of an insolvency law on an economic system according to a different method vis-à-vis the one that is adopted by the literature so far.

The common linkage of the above mentioned banks - and countries - leads to the Basel Committee on Banking Supervision, hereafter the Committee. It was established by the central-bank Governors of the "Group of Ten" countries at the end of $1974^{102}$.

In 1988 the Committee introduced the Basel Capital Accord, that is to say a capital measurement system envisaged to provide a credit risk measurement framework with a minimum capital standard of 8 per cent ${ }^{103}$. The function performed by such a minimum regulatory capital requirement is that to be an adequate buffer should an unexpected loss occur ${ }^{104}$.

In June 1999, the Committee issued a proposal for a New Capital Adequacy Framework to replace the 1988 Accord. This New Basel Capital Accord (hereafter NBCA) is still under way. In October 2003 the Committee committed to finalizing the Accord by not later than mid-2004. Currently, implementation date of NBCA should be on 31 December 2006.

Among the new principles set forth within the NBCA, the most important issue that is now worth stressing is the relationship between the credit risk being faced by a bank and banking capital requirements. In fact, in order to accomplish better the goal of promoting safety and soundness in the financial system, according to NBCA, banks are expected to align more accurately banking capital charges with the intrinsic amount of credit risk to which a bank is exposed. To put it another way, the quality of loans granted by banks, once NBCA comes into force, is even more related to the amount of capital charges to be worked out accordingly.

${ }^{101}$ It is important to say that banks of varying levels of complexity and sophistication are also encompassed in this kind of regulation.

${ }^{102}$ Currently, the member countries are the following: Belgium, Canada, France, Germany, Italy, Japan, Luxembourg, the Netherlands, Spain, Sweden, Switzerland, United Kingdom and United States.

${ }^{103}$ See www.bis.org.

${ }^{104}$ As far as the credit risk is concerned, it is made up of two elements: expected loss and unexpected loss. The former is taken into account on accounting basis by means of annual loan-loss provisions, the latter is not coped with anything else other than the bank's own capital given its intrinsic degree of uncertainty. 
As a result, capital requirements are, on the one hand, an even more pivotal buffer to cope with the credit risk being faced by a bank, on the other hand, an expensive burden in terms of cost of equity. As for the cost of banking equity, in fact, it works like that of any other non-financial enterprise: not only is the corporate debt costly but also the supply of equity is expected to get a return ${ }^{105}$.

The deep relationship between the quality of credit (that is to say the quality of banking exposure) being granted by a bank and its required capital charge (which is about to be set forth within the NBCA) makes this method far too appropriate for the measurement of the impact of an insolvency law on the economic system.

Let us see what is the connection between the NBCA and an insolvency law. Any insolvency system brings about losses to all creditors involved in a bankruptcy event. If attention is paid to banks - as main financial creditors - there can be maintained that granting loans to firms which probably will default results in a higher cost due to the increased bank's capital position. In other words, within this scenario any banking industry meet an "insolvency-law cost" in order to comply with safety and soundness in the financial system ${ }^{106}$. This sort of cost, to the same extent, passes on to the borrower in terms of a greater interest rate ${ }^{107}$. Therefore, an insolvency law, on its own, implies an incremental cost of banking credit because a defaulted borrower is unable to pay back its loan entirely. To this point the kind and quality of a given insolvency regulation is essential to the extent that (given a recovered percentage) it greatly affects the way banks collect this percentage of collectable credit. The longer and more cumbersome the collection is due to the insolvency framework, the costlier the banking credit is ${ }^{108}$.

${ }^{105}$ With reference to a given firm that resorts to both credit and equity, stocks cost the firm more than bonds do. In fact, since bonds are promises to pay, their return is made up of two parts: a) risk-free rate; b) risk premium. Stocks, on the other hand, pay a higher return due to their riskier status: a) risk-free rate; b) risk premium; c) growth (the higher value to make up firm's shareholders for the absence of any promised interest like for bonds).

${ }^{106}$ This cost refers to those corporate borrowers that have gone bankrupt.

${ }^{107}$ It is important to say that this is not an unfair practice but the basic principle to be applied in lending activity when the event of credit risk is taken into account. For an important work on this subject, see Saunders (1994).

${ }^{108}$ In fact, given the percentage recovered at the end of the procedure, the net present value of the credit collected is greatly eroded by the length of the procedure. Moreover, the kind of insolvency regulation also affects the amount that can be collected other than the net present value of a given amount. 
The case for an effective insolvency regulation is even more important if the need for a level playing field among countries is taken into account. In fact, in order for markets to perform as the ideal mechanism for allocating resources, regulatory competitive disadvantages should be dismantled.

The next step, then, consists in measuring the effectiveness and the efficiency of an insolvency regulation by means of a sensitivity analysis approach which takes into account, according to a benchmarking analysis, the two key parameters of any insolvency framework: a) the rate a bank is able to recover its exposure at default (recovery rate); b) how long a bank takes to recover its exposure (recovery time).

If in country A the insolvency law was less efficient and effective than that in country $\mathrm{B}$, in the former case a corporate borrower would pay more than an equivalent enterprise borrowing in the latter case. Moreover, in country A, the higher the probability of default of a corporate is ${ }^{109}$, the greater the "insolvency-law competitive disadvantage" paid by this firm.

It should now be clear the potential reach and suitability that can be acknowledged to the NBCA as a measure of the impact of an insolvency system. To put it another way, the new capital adequacy framework becomes eligible to assess the quality of a given insolvency regulation in comparison with other insolvency frameworks. Even though this method of measurement focuses on the banking industry, the findings of such a method itself apply to the economic system as a whole. Capital requirements according to NBCA might be bound to be considered as a sort of a neutral speedometer of the effectiveness and the quality of an insolvency law. Although any ailing firm can enter a bankruptcy proceeding, both liquidation and restructuring, for different reasons one of the common features at any event is the presence of a lending bank among the creditors facing the insolvency procedure. As a result, the two assumptions of analysis are used in different terms. Firstly, the subjective assumption has not to do with distressed enterprises but applies to all the existing enterprises within an economic system ${ }^{110}$. Secondly, the objective assumption considers the differential cost of credit as the means of measure of the degree of efficiency and effectiveness of an insolvency system.

\footnotetext{
${ }^{109}$ In order to be affected by an inefficient insolvency law, in terms of higher cost of banking credit, there is no need for a firm to go bankrupt. It is enough the condition of PD $>0$.

${ }^{110}$ In fact, the probability of default refers to corporations that are not currently involved in any insolvency procedure.
} 
Finally, in order to understand better the following application of the NBCA method to an insolvency law, it is essential to practice with some buzz words used by the Committee:

$\checkmark$ Exposure at default (hereafter, EAD): amount to which the bank was exposed to the borrower at the time of default;

$\checkmark$ Probability of default (hereafter, PD): probability of default of a borrower or group of borrowers;

Loss given default (hereafter, LGD): how much banks will lose should a borrower default on an obligation; it is expressed as a percentage of the exposure.

\subsection{Estimating the impact of Italian insolvency law: an empirical application of the new approach}

The Italian bankruptcy law in force so far has not revealed itself as particularly effective and efficient. In fact, far for adhering to the best practice surveyed by an IMF paper ${ }^{111}$, in Italy: a) "creditors have often been unable to collect their claims, so as to adversely affect the future availability of credit" $"$; b) "The rights of debtors (and their employees) may not be adequately protected" ${ }^{113}$. Moreover, according to the World Bank, "[e]ffective insolvency and creditor rights systems are an important element of financial system stability"114.

So far, several surveys have been performed with regard to the recovery of banking loans under the current insolvency law ${ }^{115}$; among them, the research by Banca d'Italia (2002) is the source of information in the present research ${ }^{116}$.

\footnotetext{
${ }^{111}$ International Monetary Fund (1999).

${ }^{112}$ International Monetary Fund (1999).

${ }^{113}$ International Monetary Fund (1999).

${ }^{114}$ World Bank (2001).

115 The literature with regard to Italian insolvency law is extremely wide. Some of the most important are as follows: Generale, A., and G. Gobbi (1996); Banca d'Italia (1999); Boccuzzi, G., and R. Cercone (1993); Caprio (1997); Belcredi, M., (1995a; 1995b); Cornelli, F., and Felli L., (1994); Belcredi, M., and Floreani A. (1997).

${ }^{116}$ For little earlier information, see Associazione Bancaria Italiana and Università Bocconi (2000).
} 
36 A Basel II - based quantitative application to bankruptcy in Italy

Nowadays bankruptcy proceedings last, on average, 7 years. Annually, recovery action costs banks an average of $€ 1.2$ per 100 of debt ${ }^{117}$.

Currently, it may be estimated that banks can recover from an insolvent firm, on average, $€ 38$ of 100 of their exposure at default ${ }^{118}$.

Now a cumulative recovery function is plotted. It represents the EAD's percentage being recovered by the bank from an insolvent corporate client throughout the entire recovery time of 7 years.

The recovery rate being equal ( 38 per cent), the first question to address is how the cumulative recovery function changes by decreasing the length of the procedure. To put it another way, given the two key parameters - the recovery rate and the recovery time - the former is kept the same, the latter is considered as a variable one. Then, to the current scenario of 7 years of length, three more scenarios are added: respectively of 6,5 and 3.5 years. The third scenario may be considered the "best case" scenario; this represents the average length of bankruptcy proceedings in the main EU countries.

By means of a zero coupon yield curve ${ }^{119}$, the following step is to work out the net present value (NPV) for each of the four cumulative recovery functions, also taking into account that banks meet yearly operational costs amounting to $€ 1.2$ of $€ 100$ of EAD (FIGURE A). How does the NPV change by reducing the length of the procedure?

${ }^{117}$ Meant as exposure at default.

${ }^{118}$ Since the topic of this research is the Italian bankruptcy law, it is important to say that the method that follows is not applied to bad loans as a whole but only to those that are involved in bankruptcy proceedings; this part accounts for 21 per cent of all bad loans. See Bank of Italy (2002).

${ }^{119}$ Source: Reuters, Euro zero coupon yield curve, $4^{\text {th }}$ February 2003. 


\section{Cumulative recovery function}

The recovery rate (38\%) being equal, how does the cumulative recovery function change by decreasing the length of the proceeding?

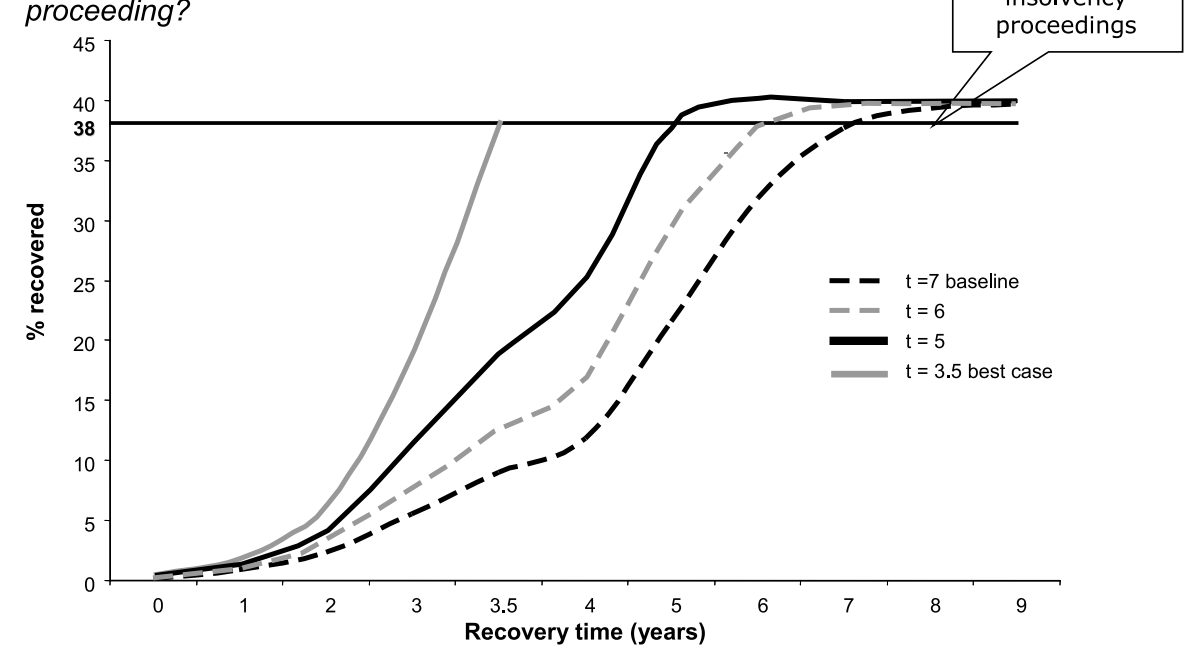

Figure A: Variable parameter: Length of Proceeding

Within the current Italian insolvency framework, a bank commencing a bankruptcy procedure has an expected NPV of $€ 24.58$. In fact, the $€ 38$ that is the expected amount to be recovered at the end of the proceeding is mostly eroded (almost 35 per cent) by both the length of the procedure and the yearly operational costs, that in turn are affected by the length itself.

If the bankruptcy system was streamlined to some extent that the average length was reduced to, respectively, 6 or 5 years instead of the current 7 years, the NPV rises to 26.31 ( +7 per cent if compared to the previous 24.58) or 28.07 ( +14 per cent).

The improvement in the NPV is much higher if the best case scenario is applied. In fact, if the Italian insolvency law was as long as the average of the main EU countries, the expected NPV is $€ 30.77$ (an increase of 25 per cent if compared with the NPV at the baseline).

A first conclusion that can be drawn is that, given the recovered amount, the lower the length of the Italian bankruptcy proceeding, the higher the expected net present value of the amount that a bank can expect to recover from an insolvent borrower corporation. 
Let us skip now to the following step. After a sensitivity analysis in which the variable parameter was the recovery time, this time the same method is applied being the recovery rate the variable parameter.

Four scenarios are taken into account: the starting point is represented by the current recovery rate ( 38 per cent), the two intermediate better scenarios are respectively of 45 per cent and 50 per cent, finally, the best case scenario amounts to 55 per $\operatorname{cent}^{120}$ (FIGURE B).

\section{Cumulative recovery function}

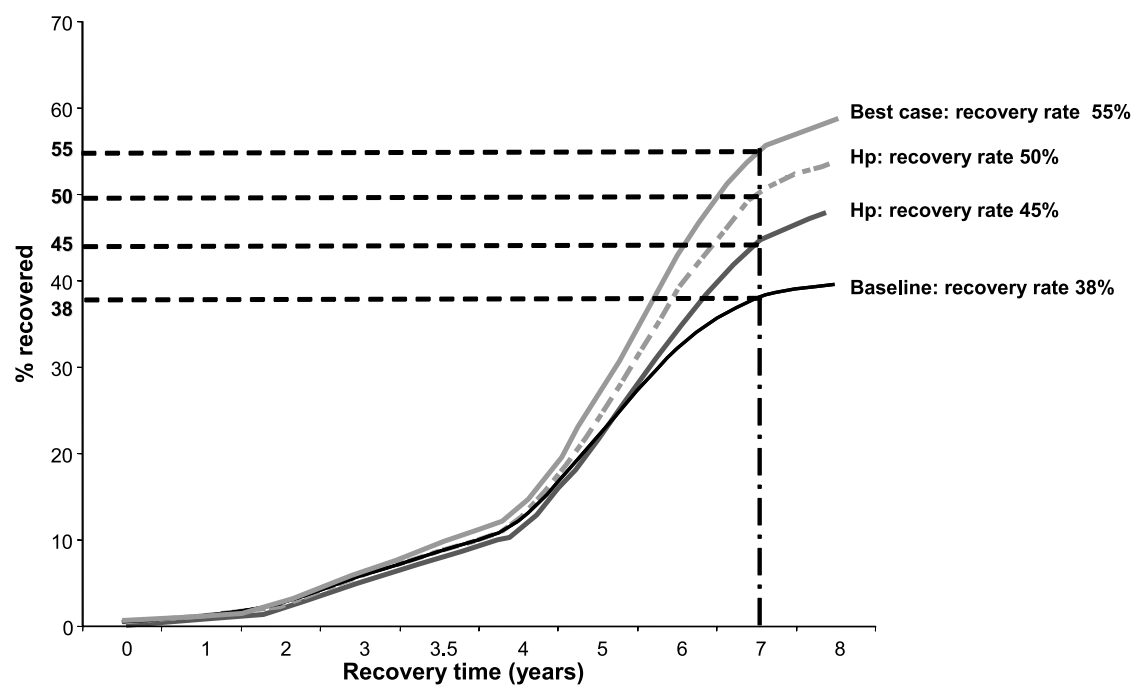

Figure B: Variable parameter: Recovery Rate

The length of the proceeding being equal - 7 years - and given that banks meet yearly operational costs amounting to 1.2 out of $€ 100$ of EAD, the aim, this time, is to work out how NPV changes by increasing the recovery rate due to an improvement of the Italian insolvency law.

Starting from the expected NPV of $€ 24.58$ out 100 within the current combination of 7 years as recovery time and 38 per cent as recovery rate, any further improvement of insolvency system would result in better outcomes.

${ }^{120}$ The percentage of 55 per cent has been chosen to prudentially approximate the LGD parameter within the Basel Committee. In fact, according to Basel Committee on Banking Supervision (2001a), the benchmark risk weight denotes the corporate benchmark risk weight associated with a given PD, which is calibrated to an LGD of 50 per cent. However, by using 55 per cent as the best-case recovery rate, the corresponding LGD is not as much as the benchmark set forth in NBCA but is still higher. 
At a recovery rate of, respectively, 45 per cent and 50 per cent their corresponding NVP are $€ 30.04$ ( +22 per cent if compared with the NPV at the baseline) and $€ 34.15$ ( +39 per cent).

The outcome of streamlining Italian insolvency framework is achieved better by increasing the recovery rate as envisaged in the best-case scenario: in case of a 55-per cent recovery rate the expected NVP is of $€ 38.27$ out of 100 as EAD; this performance would allow any bank to recover almost 56 per cent to a greater degree in comparison with the current nominal 38 per cent ${ }^{121}$.

The second conclusion is that given the length of the proceeding, the higher the recovery rate, the higher the NPV.

There are now three different scenarios to be taken into account in order to estimate the impact of the current Italian insolvency regulation on the economic system. Apart from the current scenario which is also the baseline benchmark for this research, two more virtuous and alternative ones come to the fore (FIGURE C).

\section{Scenarios on which the impact of insolvency regulation is calculated}

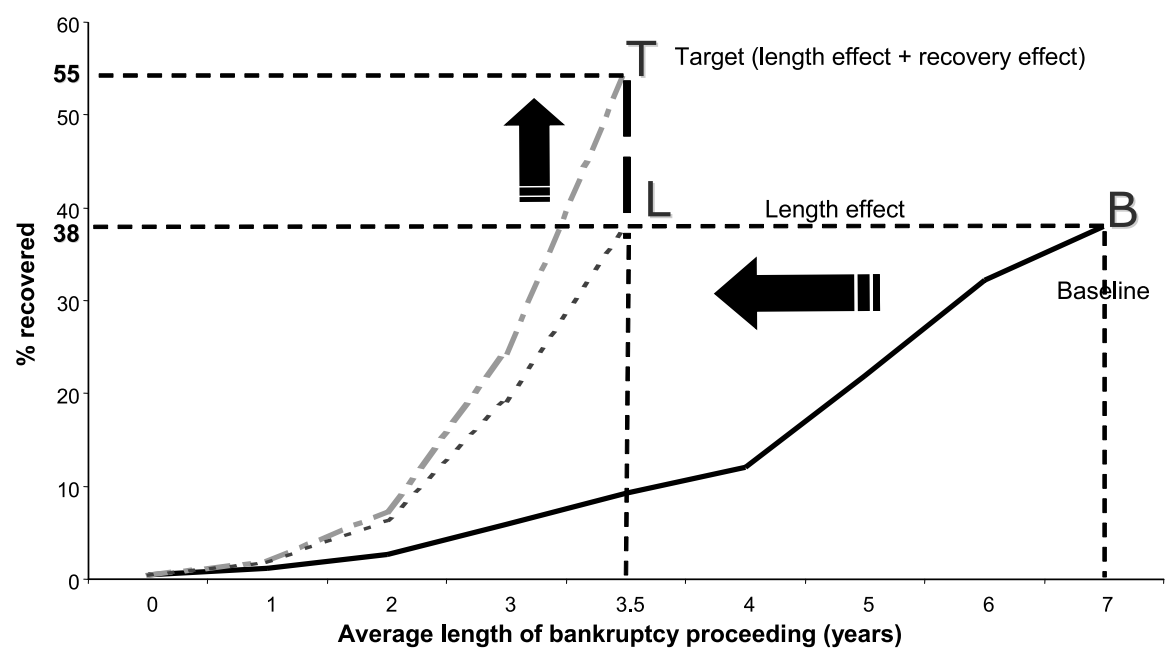

Figure C: Scenarios at Stake

\footnotetext{
${ }^{121}$ This nominal figure is equal to a NPV of 24.58.
} 
At an intermediate level, there is a scenario where only a length effect is taken into account. This scenario is made up of a combination between the same recovery rate as the baseline ( 38 per cent) and a lower average length of bankruptcy proceeding ${ }^{122}$.

The third scenario is the target one: this consists in a combination between the length effect (recovery time of 3.5 years) and the recovery effect (recovery rate of 55 per cent).

Once that NPVs have been worked out, the following step is to find for each of them the related LGD ${ }^{123}$, that is to say how much banks will lose should a borrower default on an obligation.

Some important information can be drawn from FIGURE D. Just skipping from the baseline to the intermediate one, LGD decreases to 69.23 from its peak (current level) of 75.24. Moreover, if the target scenario is compared with the intermediate one, the decrease in LGD is even larger: from 69.23 to $€ 53.85$ that is the lowest level in this research. It is important to say that the best-case LGD has to be compared with the "threshold" of 50 per cent that is the parameter to which NBCA calibrates the benchmark risk weight. As a result, the differential higher LGD experienced within the current Italian insolvency system compared with the lower NBCA benchmark can be considered as a regulatory disadvantage on Italian economy due to the current insolvency regulatory framework.

\footnotetext{
${ }^{122}$ The same length as that experienced in the main EU countries (i.e. 3.5 years).

${ }^{123}$ The relationship between NPV and LGD is as follows: LGD $=1-$ NPV. With regard to LGD the same caveat as the one in a previous footnote applies: loss given default is worked out by only accounting of bad loans involved in bankruptcy proceedings. The Associazione Bancaria Italiana has published some relevant works about both credit risk management and LGD: see Associazione Bancaria Italiana (1995) and (2002).
} 


\section{Finally, a more effective and efficient insolvency system results in much lower levels of LGD...}

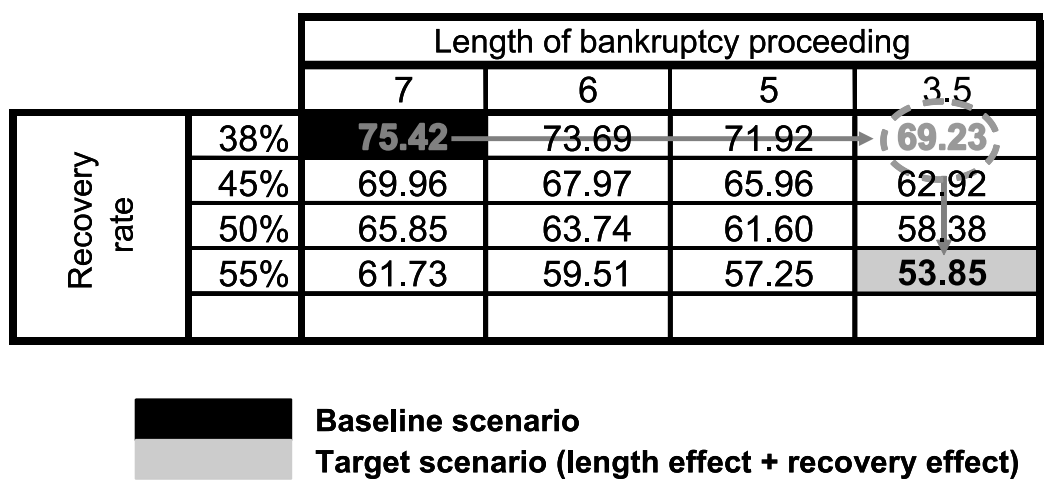

Figure D: Impact Evaluation

Finally, there remains to apply the three LGDs (those referring to respectively baseline, intermediate scenario and target scenario) to the formulas proposed by the Committee ${ }^{124}$. By doing that, it is possible to calculate the impact of insolvency regulation on the Italian economic system in terms of differential cost of credit being granted by the banking industry. Within the differential overall effect the recovery effect accounts for 71 per cent, while the length effect the remaining 29 per cent.

The differential cost of credit is related to the probability of default (PD) of borrower corporations. As it can be seen in FIGURE $\mathbf{E}$ the higher the PD, the greater the differential cost of credit. For instance, because of an ineffective bankruptcy law the differential cost of credit for a corporation with a PD of 1 per cent is almost 0.5 per cent; for a corporation with a PD of 3 percent the differential cost amounts to 1.06 per cent; with a PD of $5 \%$ the differential overall effect amounts to 1.6 per cent ${ }^{125}$.

${ }^{124}$ The formulas that have been applied in this research are taken from Basel Committee on Banking Supervision (2002a) and Basel Committee on Banking Supervision (2002b) with regard to the Advanced Approach. A previous consultative document was Basel Committee on Banking Supervision (2001b).

${ }^{125}$ It is important to say again that has been applied virtually since it will be adopted by banks when NBCA comes into force. 


\section{Impact of Insolvency Regulation on the Economy in Terms of Differential Cost of Credit}

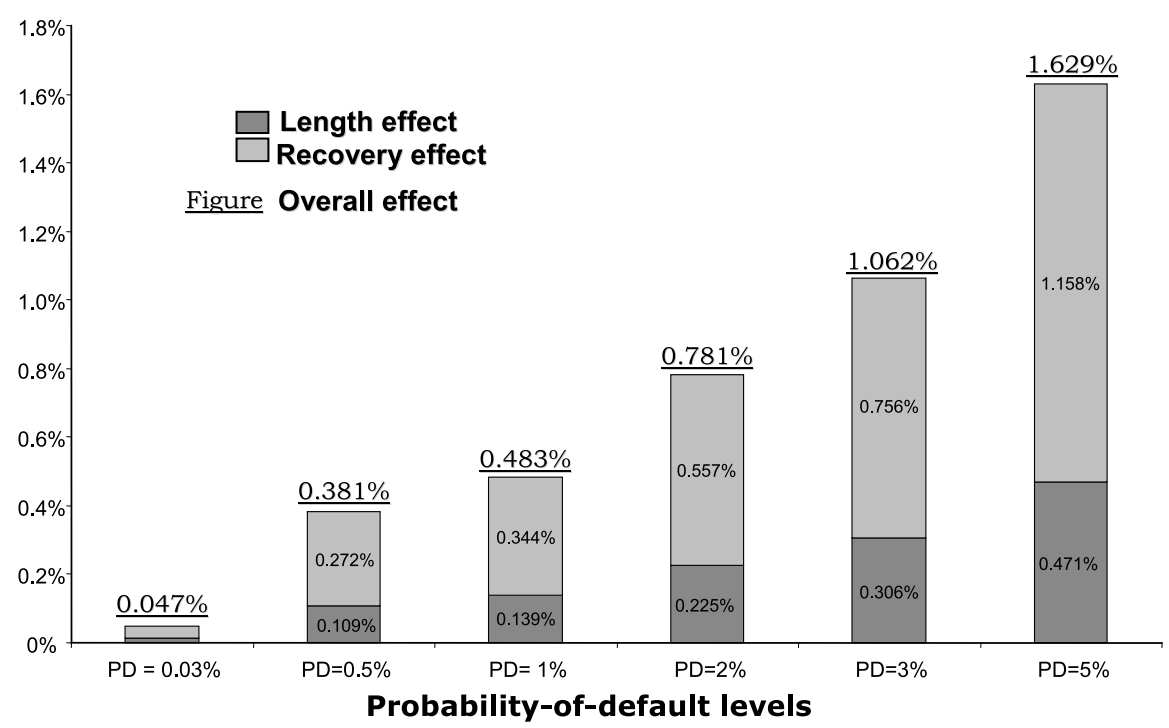

Figure E: Impact evaluation

This is the point at stake. In fact it can be observed that an insolvency law is far from affecting only corporations that have gone bankrupt. This is the proof that the whole Italian economic system suffers from such a regulatory competitive disadvantage. As a result, not only is any virtuous process impeded, but also a vicious circle can be bred by a cumbersome insolvency regulation and by the same token the economic growth of a country ${ }^{126}$ can be dwarfed.

\subsection{Conclusion}

In order to accomplish better the goal of promoting safety and soundness in the financial system, the proposal for a New Capital Adequacy Framework to replace the 1988 Accord creates an opportunity to envisage a new approach

\footnotetext{
${ }^{126}$ An interesting paper analyses the economic crises experienced by both Chile and Mexico in the early 1980s. The study concludes that the crucial difference between the former country and the latter is earlier government policy reforms in Chile, particularly reforms in policies affecting the banking system and bankruptcy procedures. See Bergoeing, R., P. J. Kehoe, T. J. Kehoe and R. Soto (2002).
} 
to measuring bankruptcy costs. The relationship between the credit risk being faced by a bank and banking capital requirements is among the new principles set forth. The quality of loans granted by banks, once New Basel Capital Accord (NBCA) comes into force, is even more related to the amount of capital charges to be worked out accordingly. As a result, this NBCA principle is well suited to measure the impact of an insolvency law on an economic system.

Based on some data provided by several surveys that have been performed with regard to the recovery of banking loans under the current insolvency law, such a new analysis has been applied to Italy. According to the current framework (baseline), bankruptcy proceedings last, on average, 7 years; annually, recovery action costs banks an average of $€ 1.2$ per 100 of debt; banks can recover from an insolvent firm, on average, $€ 38$ of 100 of their exposure at default.

This study has analysed two more scenarios. At an intermediate level, there is a scenario where only a length effect is taken into account. This scenario is made up of a combination between the same recovery rate as the baseline (38 per cent) and a lower average length of bankruptcy proceeding. The second scenario is the target one: this consists in a combination between the length effect (recovery time of 3.5 years) and the recovery effect (recovery rate of 55 per cent).

Finally, this study has measured the impact of current Italian insolvency regulation on economic system as a whole in terms of differential cost of credit.

With regard to the three scenarios which have been taken into account, within the differential overall effect the recovery effect accounts for 71 per cent, while the length effect the remaining 29 per cent. Moreover, the differential cost of credit is related to the probability of default (PD) of borrower corporations: the higher the $\mathrm{PD}$, the greater the differential cost of credit.

The previous findings hold that an insolvency law affects all not-insolvent corporations other than those corporations that have gone bankrupt. As a result, the whole Italian economic system suffers from a regulatory competitive disadvantage. 


\section{General conclusion}

This paper is aimed at giving empirical methods of evaluating the efficiency of bankruptcy legislation. The conceptual approach, illustrated in the first part, is that efficiency is linked primarily to creditor protection and only subordinately to the ability of the juridical system to coordinate creditors' actions. In the two following parts we develop two different (and, we hope, complementary) techniques for evaluating the efficiency of bankruptcy legislations according the principles depicted in the first part: in the second part, the proposed new rating scheme aims at solving what we see as some failings of the presently most used rating scheme ${ }^{127}$, which focuses too narrowly on a set of pre-defined variables without (i) evaluating bankruptcy procedures in their entirety and (ii) without taking into account the other credit-recovery schemes such as enforcement proceedings and contractual agreements; in the third part, we introduce a new approach using the cost of credit as an indirect indicator of the efficiency of bankruptcy legislations. In particular, it is argued that the New Basel Capital Accord which is about to be introduced is far too suitable for being considered as a sort of objective and neutral "speedometer" which measures the level of relative efficiency of a given insolvency regulation of any country. As a by-product of such a comparison among insolvency regulations, the case for a sort of competition among different bankruptcy frameworks can become more likely.

${ }^{127}$ La Porta and Silanes (2001). 


\section{References:}

Åbjörnsson R., (2002), Sweden, in Restructuring and Insolvency 2002, Global Counsel Handbooks, pp. 115-118, London.

Achillas C., (2002), France, in Restructuring and Insolvency 2002, Global Counsel Handbooks, pp. 43-46, London.

Adler B., (1993), Financial and Political Theories of American Corporate Bankruptcy, Stanford Law Review, vol. 45, p. $311 \mathrm{ff}$.

Aghion P., O. Hart and J. Moore, (1992), The Economics of Bankruptcy Reform, Journal of Law, Economics and Organization, vol. 8, p. 523-46.

Alchian A. A., (1965), Some Economics of Property Rights, Il Politico, vol. 30, p. 816-29, 1965, reprinted in A. A. Alchian, Economic Forces at Work, Indianapolis, Liberty Press, 1977.

Alessi G., (1998), La riforma dell'amministrazione straordinaria, Il fallimento, n. 2, pp. 113-6.

Aleth, Franz, and H. Arno Magold, (2002), Germany, in Restructuring and Insolvency 2002, Global Counsel Handbooks, pp. 49-52, London.

Allen F., and D. Gale, (2000), Comparing Financial Systems, The MIT Press, Cambridge, Massachusetts.

Altman E.I., (1984), A Further Investigation of the Bankruptcy Cost Question, Journal of Finance, vol. 39, pp. 1067-1089.

Ang J.S., J.H. Chua, and J.J. McConnell, (1982), The Administrative Costs of Corporate Bankruptcy: a Note, Journal of Finance, vol. 37, pp. 219-226.

Associazione Bancaria Italiana, (1995), Metodi avanzati per la gestione del rischio di credito, Commissione Tecnica per gli Studi, January.

Associazione Bancaria Italiana, (2002), Loss Given Default: aspetti metodologici e proposta di una struttura dati per la stima, I lavori delle Commissioni Tecniche, November.

Associazione Bancaria Italiana and Universit Bocconi, (2000), La giustizia civile è efficiente?, Bancaria Editrice, Rome.

Baird D.G., (1986). The Uneasy Case for Corporate Reorganizations, 15, Journal of Legal Studies, pp. 127-47.

Baldwin C., and S. Mason, (1983), The Resolution of Claims in Financial distress. The case of Massey Ferguson, Journal of Finance, vol. 38, pp. 505-523.

Banca d'Italia, (1999), La riforma delle procedure concorsuali. Le soluzioni normative negli Stati Uniti e in alcuni paesi europei, mimeo.

Banca d'Italia, (2002a), Relazione annuale per il 2001, Roma.

Banca d'Italia, (2002b), Survey on bank loans recoveries, Economic Bulletin, N. 34, March.

Barca F., (1994), Allocazione e riallocazione della propriet e del controllo delle imprese: ostacoli, intermediari, regole; in Banca d'Italia, Il mercato della proprietà e del 
controllo delle imprese: aspetti teorici e istituzionali, pp. 11-60.

Basel Committee on Banking Supervision, (2001a), The New Basel Capital Accord, Consultative Document, January.

Basel Committee on Banking Supervision, (2001b), The Internal Ratings - Based Approach, Consultative Document, January.

Basel Committee on Banking Supervision, (2002a), Quantitative Impact Study 3 - Technical Guidance, Consultative Document, October.

Basel Committee on Banking Supervision, (2002b), Quantitative Impact Study 3 - Instructions, Consultative Document, October.

Bebchuk, L., (1988), A New Approach to Corporate Reorganization, Harvard Law Review, p. 775-804.

Belcredi M., (1995a), Vent'anni di crisi di impresa in Italia: risultati di un'indagine empirica, Finanza Marketing e Produzione, vol. 13, pp. 81-149.

Belcredi M., (1995b), Crisi d'impresa e ristrutturazione finanziaria, Vita e Pensiero, Milan.

Belcredi M. and A. Floreani, (1997), Bankruptcy and workouts among large firms in Italy: two waves of financial distress mimeo, CESFI-Università Cattolica, Milan.

Bergoeing R., P.J. Kehoe, T.J. Kehoe, and R. Soto, (2002), Decades Lost and Found: Mexico and Chile Since 1980, Federal Reserve Bank of Minneapolis Quarterly Review, Winter, Vol. 26, No. 1, pp. 3-30.

Berle A., and G. Means, (1933), The Modern Corporation and Private Property, New York, Macmillan.

Betker B., (1995), The Administrative Costs of Debt Restructurings, Working Paper, Ohio State University.

Bhandari J.S., and L.A. Weiss (eds.), (1996), Corporate Bankruptcy. Economic and Legal Perspectives, Cambridge University Press.

Bianco M., and S. Chiri, (1997), Le partecipazioni bancarie nelle imprese in Italia: investimenti e ristrutturazioni finanziarie, in Banca, Impresa, Società, n. 3, pp. 393-426.

Bianco M., and M. Marcucci (2001), Quali procedure fallimentari? Una valutazione comparata, mimeo.

Boccuzzi G., and R. Cercone, (1993). Tutela dei creditori e riallocazione dell'impresa nella normativa fallimentare, Temi di discussione, $\mathrm{N}^{\circ} 204$, Banca d'Italia, Rome.

Bonin J. P., and M. E. Schaffer, (1999), Revisiting Hungary's Bankruptcy Episode, mimeo.

Bowers, J. W., (1990), Groping and Coping in the Shadow of Murphy's Law: Bankruptcy Theory and the Elementary Economics of Failure, Michigan Law Review, vol. 88, p. 2.097-2.150.

Bowers J. W., (1997), Security Interests, Creditors Priorities and Bankruptcy, in Encyclopedia of Law and Economics, Bouckaert, B. and De Geest, G. (eds.), Aldershot, Edward Elgar. (also available on www.encyclo.findlaw.com).

Bradley M., and M. Rosenzweig, (1992), The Untenable Case for Chapter 11, Yale Law Journal vol. 101, p. 1.043 ss.

Buonocore V. (ed.), (1999), Manuale di diritto commerciale, Torino, Giappichelli. 
Campobasso G. F.,(1999), Diritto commerciale, vol. 3; Torino, Utet.

Cappiello S., (2002), Bankruptcy Procedures in Italy: Current Framework and Prospective Reforms, International Company and Commercial Law Review, vol. 13, n. 6.

Caprio L., (ed.), (1997), Gli strumenti per la gestione delle crisi finanziarie in Italia: un'analisi economica, Studi e Ricerche, Mediocredito Lombardo, Milan.

Carriero G., (1994), La nuova disciplina dei privilegi nel finanziamento dell'impresa, Il Foro Italiano, V, 227.

Cheung S.N.S., (1983), The Contractual Nature of the Firm, Journal of Law and Economics, April.

Cirenei M.T., (1999), La riforma dell'amministrazione straordinaria alla luce della disciplina comunitaria degli aiuti: fine di un contenzioso?, Diritto Commerciale Internazionale, p. $525 \mathrm{ff}$.

Citron D., M. Wright, R. Ball and F. Rippington, (2002), Secured Creditor Recovery Rates from Management Buy-outs in Distress, mimeo.

.Claessens S., and L.F. Klapper, 2002, Bankruptcy Around the World: Explanation of its Relative Use, World Bank Policy Research Working Paper 2865, July.

Coase R., (1937), The Nature of the Firm, Economica, vol. 4.

Coase R., (1960), The Problem of Social Cost, Journal of law and Economics, vol. 3.

Cornelli F. and L. Felli, (1994), Efficiency of bankruptcy procedures, Temi di discussione N. 245, Banca d'Italia, Rome.

Couwenberg O., (s.d.). Survival Rates in Bankruptcy Systems: Overlooking the Evidence; mimeo.

Cutler D., and L.H. Summers, (1988), The Cost of Conflict Resolution and Financial Distress: Evidence from the Texaco-Pennzoil Litigation, Rand Journal of Economics, vol. 19, pp. 157-172.

De Jasay A., (1991), Choice, Contract, Consent: A Restatement of Liberalism, London, The Institute of Economic Affairs.

Demsetz H., (1964), The Exchange and Enforcement of Property Rights, Journal of Law and Economics, October, reprinted in Harold Demsetz, Ownership, Control, and the Firm, The Organization of Economic Activity, vol. I, Oxford, Basil Blackwell 1988.

Demsetz H., (1967), Toward a Theory of Property Rights, American Economic Review, May, reprinted in Harold Demsetz, Ownership, Control, and the Firm, The Organization of Economic Activity, vol. I, Oxford, Basil Blackwell 1988.

Denis D. K. and J. J. McConnell, (2003), International Corporate Governance, mimeo.

Djankov S., R. La Porta, F. Lopez-de-Silanes and A. Shleifer, (2001), Legal Structure and Judicial Efficiency, the Lex Mundi Project, mimeo.

Franks J., and O. Sussman, (2000a), The Cycle of Corporate Distress, Rescue and Dissolution: A Study of Small and Medium Size UK Companies, mimeo.

Franks J., and O. Sussman, (2000b), Resolving Financial Distress By Way of a Contract: an Empirical Study of Small UK Companies; mimeo.

Franks J., K. Nyborg and W. Torous, (1996), A Comparison of US, UK, and German Insolvency Codes, 25 Financial Management, pp. 86-101. 
Galanti E., (2000), Garanzia non possessoria e controllo della crisi di impresa: la floating charge e l'administrative receivership, in Quaderni di ricerca giuridica della Consulenza legale della Banca d'Italia, n. 51.

Galbraith J. K., (1967), The New Industrial State, Boston, Houghton Mifflin.

Gambino A., (2000), Le procedure concorsuali minori: prospettive di riforma e la rinnovata amministrazione straordinaria, Il fallimento, n. 1, p. 5-8.

Garcin W., and F. Hepp, eds., (2001), Recueil pratique du droit des affaires dans les pays $d u$ Marché commun, Allemagne, Paris, Jupiter.

Generale A., and G. Gobbi, (1996), Il recupero dei crediti: costi, tempi e comportamento delle banche, Temi di dicussione $\mathrm{N}^{\circ} 265$, Banca d'Italia, Rome.

Gilson S., K. John and L. Lang, (1990), Troubled Debt Restructurings: an Empirical Study of Private Reorganization of Firms in Default, Journal of Financial Economics, vol. 27 , pp. 315-354.

Goode R., (1988), Legal Problems of Credit and Security, London.

Hart O., (2000), Different Approaches to Bankruptcy, www.nber.org/papers/w7921.

Hayek F. A., (1949), Individualism and Economic Order, Chicago, The University of Chicago Press.

Hayek F. A., (1967), Studies in Philosophy, Politics and Economics, Chicago, The University of Chicago Press.

Hasan Sabi, (2000), Benchmarks - money doesn't stand still - the strict criteria for claiming interest from the court on its awards; 97 Law Society Gazette, n. 21, p. 43.

Hansmann H., R. Kraakman and R. Squire, (2002), Legal Entities, Asset Partitioning, and the Evolution of Organizations, November, mimeo.

Insol Lenders Group, (1997), Global Approach to Workouts, London.

International Monetary Fund, (1999), Orderly and Effective Insolvency Procedures, Washington D.C.

Institute for Studies and Economic Analysis, (2001), Rapporto trimestrale, April

Jackson T. H., (1982), Bankruptcy, Non-Bankruptcy Entitlements, and the Creditors' Bargain, Yale Law Journal, vol. 91, pp. 857-907.

Jackson Thomas H., and Anthony T. Kronman, (1979), Secured Financing and Priorities Among Creditors, 88 Yale Law Journal: 1143-82.

Jensen M.C., and W.S. jr Smith, (1984) The Modern Theory of Corporate Finance, New York, McGraw Hill Inc.

Jensen M. C., (1989), Active Investors, LBOs, and the Privatization of Bankruptcy, Continental Bank Journal of Applied Corporate Finance, vol. 2, p. 35-44.

Jensen M. C., (1991), Corporate Control and the Politics of Finance, Journal of Applied Corporate Finance, vol. 4, pp. 13-33.

Jensen M. C., and C. W. Smith, (1984), The Theory of Corporate Finance: A Historical Overview, in M. C. Jensen and C. W. Smith (eds.), The Modern Theory of Corporate Finance, , New York, McGraw-Hill p. 2-20. Also available on http://www.ssrn.com.

Jensen M.C., and W. H. Meckling, (1976), Theory of the Firm: Managerial Behavior, Agency Costs and Ownership Structure, Journal of Financial Economics, vol. 3, p. 305-60. 
Jorio A., (1995), La riforma delle leggi francesi sull'insolvenza: un modello da imitare?; Giurisprudenza commerciale, I, p. 698-709.

Jorio A., (1999), Dal concordato stragiudiziale alla soluzione giudiziale delle crisi d'impresa, Il fallimento, n.7, p. 759-60.

Kamlah K., (1996), The New German Insolvency Act: Insolvenzordnung, American Bankruptcy Law Journal, 70, pp. 417-435.

La Porta R., F. Lopez-de-Silanes, A. Shleifer and R. Vishny, (1998), Law and Finance, Journal of Political Economy, December.

La Porta R., and F. Lopez-de-Silanes, (2001), Creditor Protection and Bankruptcy Law Reform, in Claessens, S., S. Djankov and A. Mody (eds.), Resolution of Financial Distress, Washington, D.C., The World Bank, p. 65-90.

Libonati B., (2001), Prospettive di riforma sulla crisi dell'impresa, in Giurisprudenza commerciale, maggio-giugno, p. 327/I-341/I.

Lopez-de-Silanes F., A. Shleifer, and R. Vishny, (1997), Legal Determinants of External Finance, Journal of Finance, vol. 52, n. 2.

Mariconda G., (1989), Trasferimenti commissori e principio di causalit, Giust. Civ. 1989, p. $1569 \mathrm{ff}$.

Matthew Bender \& Company (2001a), Doing Business in Germany, www.lexis.com.

Matthew Bender \& Company (2001b), Doing Business in the United Kingdom, www.lexis.com.

McConnel J., and H. Servaes (1991), The Economics of Pre-Packaged bankruptcy, Journal of Corporate Finance, Summer, pp. 93-97.

McMillan H., R. Nachtmann and F. Philips-Patrick, (1991), Costs of reorganizing under Chapter 11: Some evidence from the 1980's, Working Paper, U.S. Securities and Exchange Commission.

Mimeo (1999). Summary, p. 29-45.

Modigliani F., and M. Miller, (1958), The Cost of Capital, Corporate Finance, and The Theory of Investment, American Economic Review, 48, pp. 261-297.

Moody's, (2000a). Bankruptcy \& Ratings: A Leveraged Finance Approach for Europe. UK versus France and Germany; mimeo, March, also available on www.moodys.com.

Moody's, (2000b). Bankruptcy \& Ratings: A Leveraged Finance Approach for Europe. Part III: France, mimeo, June, also available on www.moodys.com.

Moody's, (2000c). Bankruptcy \& Ratings: A Leveraged Finance Approach for Europe. Part III: Germany, mimeo, November, also available on www.moodys.com.

Moody's, (2001). Bankruptcy \& Ratings: A Leveraged Finance Approach for Europe. Part IV: Italy, mimeo, May, also available on www.moodys.com.

Opler T.C., and S. Titman, (1994), Financial Distress and Corporate Performance, Journal of Finance, vol. 49, pp. 1015-1040.

Panzani L. (2001), La riforma delle procedure concorsuali: due soluzioni a confronto, Il fallimento, n. 2 p. 129-140.

Posner R., 1998, Economic Analysis of Law, $5^{\text {th }}$, Aspen Law \& Business.

Ragusa Maggiore G., (1989), Fallimento (liquidazione e ripartizione dell'attivo), in Enciclopedia Treccani, vol. 13. 
Rajak H., (2003), The Enterprise Act and Insolvency Law Reform, Company Lawyer, vol. 24(3), p. 3.

Rasmussen R. K., (1992), Debtor's Choice: A Menu Approach to Corporate Bankruptcy, Texas Law Review, 71, pp. 51-121.

Rasmussen R. K., (1994), The Ex Ante Effects of Bankruptcy Reform on Investment Incentives, Washington U. L. Q., 72, pp. 1159-1211.

Rasmussen R. K., and David A. Skeel, (1995), The Economic Analysis of Corporate Bankruptcy Law; American Bankruptcy Institute Law Review, 3, pp. 85-115.

Romani F., (1978), L'analisi economica del diritto di proprietà, proceedings of the workshop held by the Acton Society, All Souls College, Oxford, June.

Romani F., (1985), Appunti sull'analisi economica dei contratti; Quadrimestre, n. 1, 1985.

Romani F, (1986), Some Notes on the Economic Analysis of Contract Law, in European University Institute, Series A: Law Contract and Organization: legal analysis in the light of economic and social theory.

Rossi G., (1996), Crisi delle imprese: la soluzione stragiudiziale, Rivista delle società, pp. 321-37.

Santella, P., (2002a), Le procedure fallimentari in Italia e in Europa e il costo dei rimedi giuridici del credito bancario, Bancaria, December.

Santella, Paolo, (2002b), Alcune considerazioni su soluzioni alternative in tema di fallimento, La rivista del diritto commerciale, n. 3-4/5-6, 2002.

Saunders A., (1994), Financial Institutions Management, Burr Ridge, Iwin.

Schumpeter J. A., (1942), Capitalism, Socialism and Democracy, Harper \& Brothers.

Schwartz A., (2002), The Law and Economics Approach to Corporate Bankruptcy, in "Faillite et concordat judiciaire: un droit aux contours incertains et aux interférences multiples", proceedings of the conference held in Louvain-la-Neuve (Belgium) on 25 and 26 April 2002, Bruxelles, Bruylant, pp. 243-73.

Schwartz Alan, (1981), Security Interests and Bankruptcy Priorities: A Review of Current Theories, 10 J. of Legal Studies, pp. 1-37.

Schwartz A., (2002), The Law and Economics Approach to Corporate Bankruptcy, in Faillite et concordat judiciaire: un droit aux contours incertains et aux interférences multiples, proceedings of the conference held in Louvain-la-Neuve (Belgium) on 25th and 26th April 2002, Bruxelles, Bruylant, pp. 243-73.

Scott J. H. jnr., (1977), Bankruptcy, Secured Debt, and Optimal Capital Structure, 32 J. Finance, pp. 1-19.

Shandro S., (2002), England and Wales, in Insolvency \& Restructuring 2003, London, Law Business Research Ltd, p. 87-96.

Shleifer A. and R. Vishny, (1997), A Survey of Corporate Governance, Journal of Finance, vol. 52 , n. 2.

Stanley D., and M. Girth, (1979), Bankruptcy: Problems, Process, Reform, Brookings Institution, Washington, DC.

Strömberg P., (2000), Conflicts of Interest and Market Illiquidity in Bankruptcy Auctions: Theory and Test Journal of Finance, 55, pp. 2641-92.

Strömberg P., and K. Thornbull, (1996), An Empirical Investigation of Swedish 
Corporations in Liquidation Bankruptcy, EFI Research Report, Stockholm School of Economics.

Strömholm S., (2002), L'Europe et le droit, Paris, Presses Universitaires de France, 2002.

Swarting O., (2002), Insolvency and Restructuring, Sweden, Insolvency and Restructuring 2003, p. 258-64, London, Law Business Research Ltd.

Trimarchi P., (1998), Istituzioni di diritto privato, Milano, Giuffrè.

Warner J.B., (1977), Bankruptcy Costs: Some Evidence, Journal of Finance, vol. 32, pp. 337-347.

Weiss L.A., (1990), Bankruptcy resolution: Direct costs and violation of priority claims, Journal of Financial Economics, vol. 27, pp. 285-314.

White Page, Deutsche Bank, Linklaters and Pricewaterhouse Coopers (eds.) (2002), The European Restructuring and Insolvency Guide 2002/2003, London.

White M.J., (1983), Bankruptcy Costs and the New Bankruptcy Code, Journal of Finance, vol. 38, pp. 477-487.

White M.J., (1984), Bankruptcy Liquidation and Reorganization, in Logue, D., Warren, Gorham \& Lamont (eds.), Handbook of Modern Finance, Chapter 35.

Wihlborg, C. and S. Gangopadhyay, 2001, Infrastructure Requirements in the Area of Bankruptcy Law, Brookings-Wharton Papers on Financial Services.

Wood P.R., 1995, Principles of International Insolvency, Sweet \& Maxwell.

World Bank, (2001), Principles and Guidelines for Effective Insolvency and Creditor Rights Systems.

Zadra G., (2001), Intervento al convegno di Torino; in Jorio, A., (ed.) "Nuove regole per le crisi d'impresa", Milano, Giuffrè, Quaderni di Giurisprudenza commerciale n. 231.

Zanzarone G., (1989), Fallimento (effetti sui rapporti giuridici preesistenti), in Enciclopedia giuridica Treccani, vol. 13. 


\section{SUERF - \\ Société Universitaire Européenne de Recherches Financières}

SUERF is incorporated in France as a non-profit-making Association. It was founded in 1963 as a European-wide forum with the aim of bringing together professionals from both the practitioner and academic sides of finance who have an interest in the working of financial markets, institutions and systems, and the conduct of monetary and regulatory policy.

SUERF is a network association of central bankers, bankers and other practitioners in the financial sector, and academics with the purpose of analysing and understanding European financial markets, institutions and systems, and the conduct of regulation and monetary policy. It organises regular Colloquia, lectures and seminars and each year publishes several analytical studies in the form of SUERF Studies.

SUERF has its full-time permanent Executive Office and Secretariat located at the Austrian National Bank in Vienna. It is financed by annual corporate, personal and academic institution membership fees. Corporate membership currently includes major European financial institutions and Central Banks. SUERF is strongly supported by Central Banks in Europe and its membership comprises most of Europe's Central Banks (29 in total, including the Bank for International Settlements and the European Central Bank), banks, other financial institutions and academics. 


\section{SUERF STUDIES}

$1997-2002$

1. G.M.M. Gelauff and C. den Broeder, Governance of Stakeholder relationships; The German and Dutch experience, Amsterdam, 1997, ISBN 90-5143-024-8.

2. Rolf Skog, Does Sweden need a Mandatory Bid Rule, a critical analysis, Amsterdam 1997, ISBN 90-5143-025-6.

3. Corporate Governance in Central and Eastern Europe; Transition Management is a Tough Job. Two papers. Amsterdam, 1998, ISBN 90-5143-027-2.

1) Debora Revoltella, Financing Firms in East European Countries: An Asymmetric Information and Agency Costs Approach

2) Peter H. Haiss and Gerhard Fink, Seven Years of Financial Market Reform in Central Europe

4. Joseph Bisignano, Towards an Understanding of the Changing Structure of Financial Intermediation; An Evolutionary Theory of Institutional Survival, Amsterdam, 1998, ISBN 90-5143-026-4. (out of print)

5. David T. Llewellyn, The New Economics of Banking, Amsterdam, 1999, ISBN 90-5143-028-0.

6. John Calverley, Sarah Hewin, Kevin Grice, Emerging Stock Markets after the Crisis, Amsterdam, 2000, ISBN 90-5143-029-9.

7. Strengthening Financial Infrastructure: Deposit Insurance and Lending of Last Resort (two contributions), Amsterdam, 2000, ISBN 90-5143-030-2.

1) Richard Dale, Deposit Insurance in Theory and Practice

2) Christian de Boissieu and Franco Bruni, Lending of Last Resort and Systemic Stability in the Eurozone.

8. Cem Karacadag and Michael W. Taylor, The New Capital Adequacy Framework: Institutional Constraints and Incentive Structures, Vienna, 2000, ISBN 3-902109-00-9.

9. Miguel Sebastián and Carmen Hernansanz, The Spanish Banks' Strategy in Latin America, Vienna, 2000, ISBN 3-902109-01-7.

10. M.M.G. Fase and W.F.V. Vanthoor, The Federal Reserve System Discussed: A Comparative Analysis, Vienna, 2000, ISBN 3-902109-02-5.

11. Willem H. Buiter and Clemens Grafe, Central Banking and the Choice of Currency Regime in Accession Countries, Vienna, 2001, ISBN 3-902-109-03-3. 
12. Sanjiva Prasad, Christopher J. Green, and Victor Murinde, Company Financing, Capital Structure, and Ownership: A Survey, and Implications for Developing Economies, Vienna, 2001, ISBN 3-902109-04-1.

13. Martin M.G. Fase, Investment in Paintings: The interaction of monetary return and psychic income, Vienna, 2001, ISBN 3-902109-05-X.

14. Alexandre Lamfalussy, Reflections on the Regulation of European Securities Markets, Vienna 2001, ISBN 3-902109-06-8.

15. Italian Mutual Banks: Performance, Efficiency and Mergers and Acquisitions (two contributions), Vienna 2002, ISBN 3-902109-07-6.

1) Juan Sergio Lopez, Alessandra Appennini, Stefania P.S. Rossi, Evidence from two different cost frontier techniques.

2) Roberto Di Salvo, Maria Carmela Mazzilis, Andrea Guidi, Mergers and acquisitions between mutual banks in Italy: an analysis of the effects on performance and productive efficiency.

16. Thomas Reininger, Franz Schardax, Martin Summer, Financial System Transition in Central Europe: The First Decade, Vienna, 2002, ISBN 3-902109-08-4.

17. Helmut Wagner, Implications of Globalization for Monetary Policy, Vienna, 2002, ISBN 3-902109-09-2.

18. Luiz Fernando De Paula, Banking Internationalisation and the Expansion Strategies of European Banks to Brazil during the 1990s, Vienna, 2002, ISBN 3-902109-10-6.

19. Is there a Future for Regional Banks and Regional Exchanges? The Strategies of Selected Austrian Finance Institutions, (four contributions), Vienna, 2002, ISBN 3-902109-11-4.

1) David T. Llewellyn, The Future for Small \& Regional Banks inEurope

2) Reinhard Ortner, What Future for Regional Banks?

3) Herbert Stepic, The Strategy of RZB in Central and Eastern Europe

4) Stefan K. Zapotocky, The Challenges and Chances of Regional Exchanges

20. Thomas Dalsgaard, Jorgen Elmeskov, Cyn-Young Park, Ongoing Changes in the Business Cycle - Evidence and Causes, Vienna, 2002, ISBN 3-902109-12-2.

21. Christian Harm, Bank Management Between Shareholders and Regulators, Vienna, 2002, ISBN 3-902109-13-0.

22. Jean-Paul Abraham, Peter van Dijcke, European Financial Cross-Border Consolidation: At the Crossroads in Europe? By Exception, Evolution or Revolution, Vienna, 2002, ISBN 3-902109-14-9. 
2003/1 Bert Scholtens, Dick van Wensveen, The Theory of Financial Intermediation: An Essay on What it Does (Not) Explain, Vienna 2003, ISBN 3-902109-15-7.

2003/2 Paola Bongini, The EU Experience in Financial Services

Liberalization: A Model for GATS Negotiation? Vienna 2003, ISBN 3-902109-16-5.

2003/3 Jean-Paul Abraham, Introduction by David T. Llewellyn, Monetary and Financial Thinking in Europe - Evidence from Four Decades of SUERF, Vienna 2003, ISBN 3-902109-17-3.

2003/4 Securing Financial Stability: Problems and Prospects for New EU

Members (three papers) Introduction by Morten Balling, Vienna 2003, ISBN 3-902109-18-1

1) Michael C. Bonello, Stability Oriented Monetary and Prudential Policies in EU Accession Countries

2) Fabrizio Saccomanni, Ensuring Financial Stability: Global and European Perspectives

3) Claudia M. Buch, Jörn Kleinert and Peter Zajc, Foreign Bank Ownership: A Bonus or Threat for Financial Stability?

2003/5 Ralph Süppel, Russia's Financial Markets Boom, Crisis and Recovery 1995-2001, Vienna 2003, ISBN 3-902109-19-X

2004

2004/1 Supervisory Systems, Fiscal Soundness and International Capital Movement: More Challenges for new EU Members (three papers) Introduction by Morten Balling, Vienna 2004, ISBN 3-902109-20-3

1) Andreas Grünbichler and Patrick Darlap, Integration of European Supervisory Systems: Harmonisation or Unification?

2) Sinikka Salo, The Relevance of Fiscal Soundness for Monetary Stability

3) Leslie Lipschitz, Timothy Lane and Alex Mourmouras, How Capital Flowswill influence the EU Accession Countires of Central and Eastern Europe

2004/2 European Monetary and Financial Integration: Evolution and Prospects (five speeches), Introduction by Eduard H Hochreiter and David T Llewellyn, Vienna 2004, ISBN 3-902109-21-1

1) Monetary and Financial Thinking in Europe since the Sixties: Evidence from the SUERF Colloquia. By Jean-Paul Abraham 
2) Fiscal Discipline in a Monetary Union: Issues for the Euro Area. By Franco Bruni

3) Financial Globalisation and Financial Market Integration in Europe: Challenges Ahead for the European System of Central Banks, by Baron Alexandre Lamfalussy

4) How to complete the Integration of the European Financial Market, by Robert Raymond

5) Optimal Currency Areas and Implementation of Economic Policies, by Jean-Claude Trichet

2004/3 Northern and Eastern Enlargement of EMU: Do Structural Reforms

Matter? By Andrew Hughes Hallett, Svend E. Hougaard Jensen and

Christian Richter, Vienna 2004, ISBN 3-902109-22-X

2004/4 Electronic Purses in Euroland: Why do Penetration and Usage Rates

Differ? By Leo van Hove, Vienna 2004, ISBN 3-902109-23-8

2004/5 From Floating to Monetary Union: The Economic Distance between

Exchange Rate Regimes. By Eduard H. Hochreiter and Pierre L.

Siklos, Vienna 2004, ISBN 3-302109-24-6

Order Form: www.suerf.org 